\title{
The imprint of the Slave Trade in an African American population: mitochondrial DNA, $Y$ chromosome and HTLV-1 analysis in the Noir Marron of French Guiana
}

Nicolas Brucato ${ }^{1 *}$, Olivier Cassar ${ }^{2}$, Laure Tonasso ${ }^{1}$, Patricia Tortevoye ${ }^{2}$, Florence Migot-Nabias ${ }^{3}$, Sabine Plancoulaine ${ }^{2,4}$, Evelyne Guitard ${ }^{1}$, Georges Larrouy ${ }^{1}$, Antoine Gessain², Jean-Michel Dugoujon ${ }^{1}$

\begin{abstract}
Background: Retracing the genetic histories of the descendant populations of the Slave Trade $\left(16^{\text {th }}-19^{\text {th }}\right.$ centuries) is particularly challenging due to the diversity of African ethnic groups involved and the different hybridisation processes with Europeans and Amerindians, which have blurred their original genetic inheritances. The Noir Marron in French Guiana are the direct descendants of maroons who escaped from Dutch plantations in the current day Surinam. They represent an original ethnic group with a highly blended culture. Uniparental markers (mtDNA and NRY) coupled with HTLV-1 sequences (env and LTR) were studied to establish the genetic relationships linking them to African American and African populations.

Results: All genetic systems presented a high conservation of the African gene pool (African ancestry: mtDNA = 99.3\%; NRY = 97.6\%; HTLV-1 env = 20/23; HTLV-1 LTR = 6/8). Neither founder effect nor genetic drift was detected and the genetic diversity is within a range commonly observed in Africa. Higher genetic similarities were observed with the populations inhabiting the Bight of Benin (from Ivory Coast to Benin). Other ancestries were identified but they presented an interesting sex-bias. Whilst male origins spread throughout the north of the bight (from Benin to Senegal), female origins were spread throughout the south (from the Ivory Coast to Angola).

Conclusions: The Noir Marron are unique in having conserved their African genetic ancestry, despite major cultural exchanges with Amerindians and Europeans through inhabiting the same region for four centuries. Their maroon identity and the important number of slaves deported in this region have maintained the original African diversity. All these characteristics permit to identify a major origin located in the former region of the Gold Coast and the Bight of Benin; regions highly impacted by slavery, from which goes a sex-biased longitudinal gradient of ancestry.
\end{abstract}

\section{Background}

The genetic dispersal that occurred during the Slave Trade remains complex, due to the large diversity of populations involved. Modern African American populations show this genetic diversity, inherited from African, European and Amerindian populations. Nine to ten million Africans were deported to the American colonies during the $16^{\text {th }}-19^{\text {th }}$ centuries. In the Guianese regions [1], between Brazil and Venezuela, approximately

\footnotetext{
* Correspondence: brucato@cict.fr

'Laboratoire d'Anthropobiologie Moléculaire et Imagerie de Synthèse, CNRS and Université Paul Sabatier, FRE2960, Toulouse, France

Full list of author information is available at the end of the article
}

400,000 slaves arrived to work in the plantations from 1604 to 1815 for mainly Dutch, but also English, French and Portuguese Jew settlers. Although many of these slaves were shipped by the Dutch West Indische Compagnie (WIC, 1620-1674), which controlled several African trading posts notably in the Bight of Benin, most of them were sold by independent slavers who traded along the Atlantic coast of Africa. Historical reports show widespread origins of the enslaved working force in Guiana, ranging over the Atlantic African coast from Senegal to Angola: 12\% of the slaves came from Senegambia (present-day Senegal, Guinea-Bissau, Guinea), Sierra Leone and the Windward Coast (present-day 
Liberia and a part of the Ivory Coast), 56\% from the Gold Coast (the remaining part of the Ivory Coast and Ghana) and the Bight of Benin (present-day Togo, Benin and a part of Nigeria), $5 \%$ from the Bight of Biafra (the remaining part of present-day Nigeria, Cameroon, Equatorial Guinea and Gabon), and 28\% from South West Africa (present-day Angola) [2]. The slavers took advantage of this high cultural diversity, by breaking all ethnic and familial networks and by maintaining a sex-ratio $(2 / 3$ men and $1 / 3$ women) to prevent rebellions during the Middle Passage (the crossing of Atlantic Ocean) and in the plantations.

Despite these precautions, many slaves managed to escape from European oppression once on American soil, a phenomenon known as marooning. In Dutch Guiana, these maroons took refuge in the equatorial Amazonian forest, and reconstructed entire communities known as the Noir Marron (or Bushinengué) [3]. These escapes were favoured by conflicts between the Dutch and French, as was observed during the French embargo of Dutch Guiana in 1712. They rapidly adapted themselves to this new environment, to represent a real threat for the colonial power, forcing the government to sign peace treaties. Between 1760 and 1809, six Noir Marron communities were officially recognized: Saramaka, Ndjuka, Aluku, Paramaka, Matawai and Kwinti [3]. From the beginning of the $19^{\text {th }}$ century to 1986 and the Surinamese civil war, they were often evicted from their territories and many of them were forced to take refuge in French Guiana. Despite these fluctuating conditions of life, the Noir Marron communities have prospered and their culture has asserted itself. Although the maroon identity is their cornerstone, cultural exchanges with Europeans and Amerindians have been intense. Large influences are detectable, for example, in their languages composed of English, Dutch, Portuguese or Arawak words, and in the structure of their villages, which are inherited from Amerindian knowledge. Today, living in Surinam and French Guiana, 50,000 individuals constitute one of the last known American maroon society [3], and contribute to the large ethnic diversity of African American populations.

The complex variety of African American communities has been well-studied, notably with genetic data revealing a high diversity among them. These populations can be highly admixed, as an Afro-Brazilian group from the State of Saõ Paulo whose origins are at: 26\% African, 62\% European and 12\% Amerindian [4]. They can have a balanced admixed profile, as the Brazilian community of Cameta: 53\% African, 24\% European and 23\% Amerindian [5]. But some of them show a relatively preserved African ancestry, as the Gullah/Geechee in United States: 96\% African and 3\% European and 1\% Amerindian [6]. Furthermore, these studies have shown that gene-flow within each group is often sex-biased, adding another level of complexity, as in the AfroVenezuelian community of Birongo which has a maternal African inheritance of $100 \%$ and a paternal European ancestry of 93\% [5]. Concerning the Noir Marron population, a preliminary anthropological study on the Gm allotypic system showed a high degree of conservation of the African genetic contribution (95.1\%) and very low levels of European (2.6\%) and Amerindian (1.7\%) contributions. This contradicts expectations based on their cultural exchanges and emphasises the importance of the maroon identity which has shaped their profile of admixture [7]. Moreover, this seems to constitute an original genetic characteristic in comparison with other African American populations inhabiting Latin America. Although the Gm system has a high power of discrimination between continental populations, it is limited for finer-scale analyses [8]. These original findings have to be confirmed by more powerful tools. Consequently, three genetic markers have been analysed in the present study, to obtain a better picture of the genetic structure of the Noir Marron. Uniparental lineages were determined through the analysis of mitochondrial DNA (mtDNA) and nonrecombinant $\mathrm{Y}$ chromosome (NRY) haplotypes. Through the large number of African American and African populations typed for these systems, updated by original data from the Ivory Coast and Benin, the data available are informative to identify the ancestry of each haplotype observed $[9,10]$. A third particular genetic system, the HTLV-1 retrovirus, has been explored because of its interest in human populations $[11,12]$. Due to its ability to integrate itself in human genome, its low mutation rate and its mode of transmission (mainly mother-tochild), it represents a relevant marker for infected groups. For some genotypes and especially concerning the Long Terminal Repeat (LTR) region, the phylo-geographical tree is highly discriminative [12]. This study is the first to combine these three genetic systems to study an African American population. In obtaining a better understanding of the genetic structure of the Noir Marron in French Guiana, the aim of this study is dual: (i) to confirm or not the highly preserved African gene pool obtained from the $\mathrm{Gm}$ allotypic system, which contradicts the cultural exchanges between the Noir Marron, Amerindians and Europeans, and (ii) to retrace the origin of this community by estimating the contribution of the historical African areas of slavery.

\section{Methods \\ Population Samples \\ Noir Marron from French Guiana}

One hundred and forty-two DNA extracts by phenolchloroform protocol from Peripheral Blood Buffy Coat ( $P B B C$ ) from individuals belonging to the four Noir 
Marron populations in French Guiana have been collected previously, during former collaborative studies in Saint-Laurent du Maroni, Maripasoula and Papaichton in the Maroni river region [13-16]: 80 Ndjuka, 41 Saramaka, 10 Aluku and 11 Paramaka. Genealogical data has been collected upon three generations to exclude related individuals. The locations of these populations are shown in Figure 1. Informed consent was obtained from all participants and the study was performed after authorisation from the Commission Nationale de l'Informatique et des Libertés (CNIL), the Comité Consultatif de Protection des Personnes dans la Recherche Biomédicale (Necker Hospital, Paris), l'Agence Française de Sécurité Sanitaire des Produits de Santé (AFSSAPS) and the Comité de Protection des Personnes Sud-Ouest et Outremer III. Because of the sampling heterogeneity and the non-significant genetic differences observed for the Gm system among the Noir Marron communities [7], a Fst test on uniparental markers, using Arlequin v.3.11 software [17], confirmed their genetic homogeneity (Fst $<0.05$, p-value $=0.05$, data not shown). Thus, they are considered as a whole group in this study.

\section{Benin}

The Bight of Benin, also known as the "Slave Coast", was one of the African areas most impacted by slavery between the $16^{\text {th }}$ and $19^{\text {th }}$ centuries, since more than $2,340,000$ individuals were deported from its coast [2]. Thousands of people were enslaved each year and sold to European slavers in trading posts, such as in Whydah. A large part of the wealth of the Dahomey and Oyo kingdoms was based on this trade [1]. Present-day Benin is composed of more than forty different ethnic groups, the most numerous being the Fon. In an aim to enlarge the databases of this crucial region, our sampling was composed of blood samples from 82 Fon and 68 Beninese, belonging to diverse ethnic groups subjected to slavery, such as the Yoruba, Tofin and Goun. Informed consent was obtained from all participants and the study was authorised by the ethics committee of the Faculté des Sciences de la Santé at the Université d'Abomey-Calavi in Benin. The locations of these populations are shown in Figure 2.

\section{Ivory Coast}

This region was extensively used for slaves after the $18^{\text {th }}$ century. Belonging to the historical areas of the Windward Coast and the Gold Coast, approximately 700,000 Africans living in this region were deported to the Americas during the Triangular Trade [1]. Today, about 60 ethnic groups constitute the cultural diversity of the Ivory Coast. Among them, blood samples from 128 Ahizi and 62 Yacouba were collected filling a lack in the available databases. All samples were obtained with the informed consent of the participants. The locations of these two populations are shown on Figure 2.

\section{Laboratory methods \\ $m t D N A$}

Maternal lineages were determined by a two-step procedure. The entire HVS-I (positions 16012-16400), the

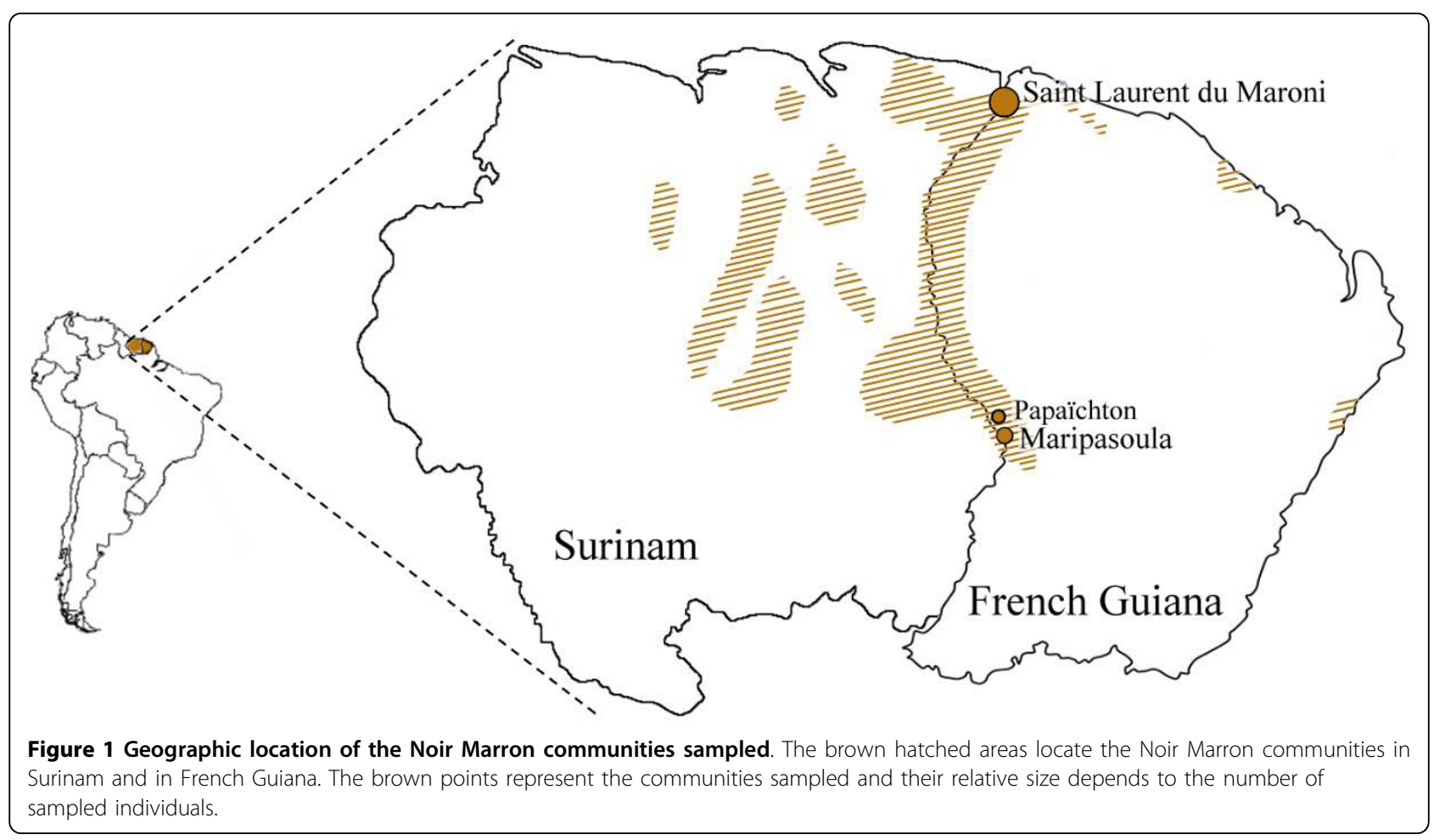




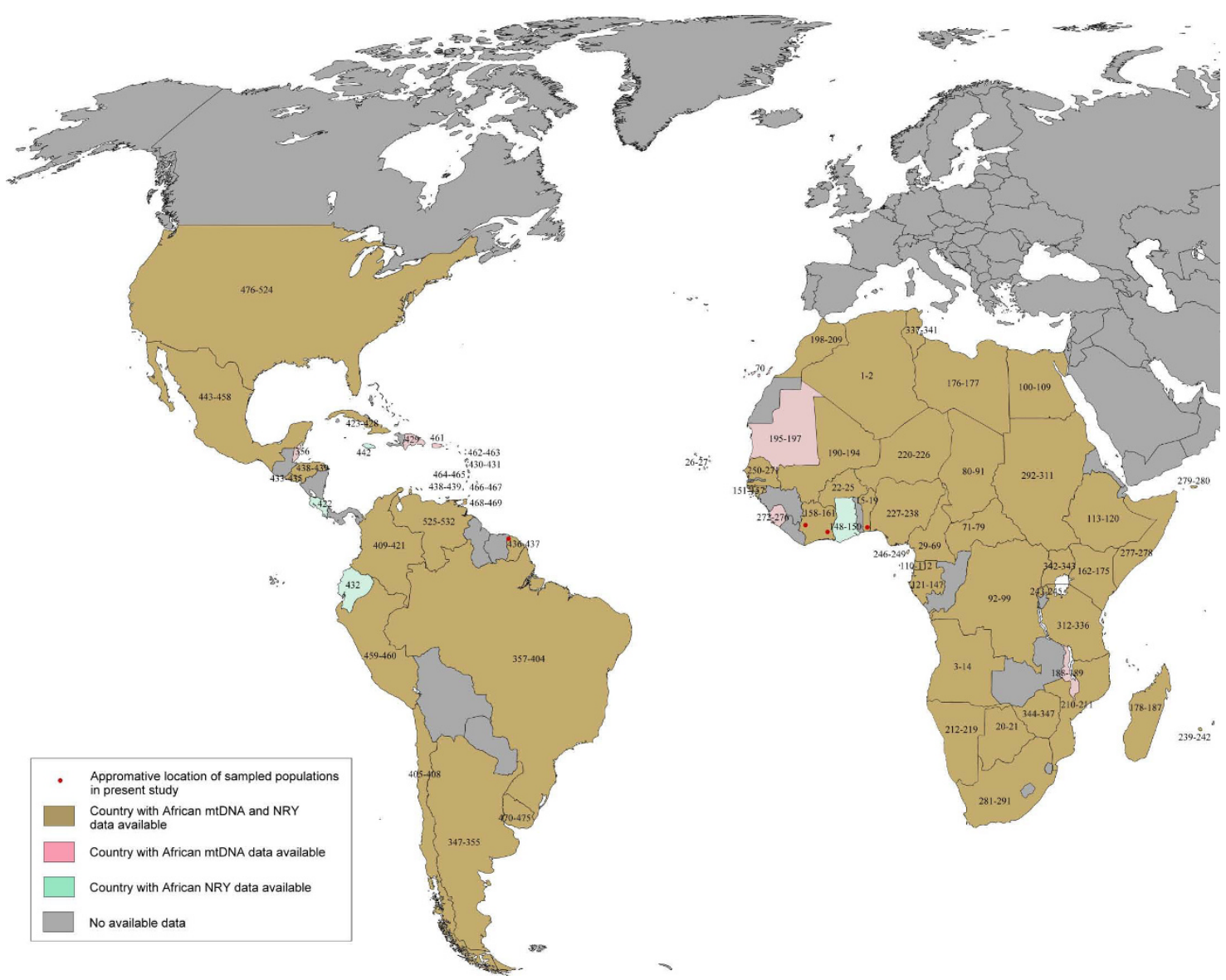

Figure 2 Geographic locations of populations analysed in the study. Each number refers to a unique group characterised by its ethnic name, country, the genetic system studied and the author of the corresponding study. The nomenclature and the references are available in Additional file 1.

intermediate region (positions 16401-72) and part of HVS-II (positions 73-263) of the mtDNA control region were sequenced following the protocol described previously [18]. A first alignment step with rCRS [19] was made using BioEdit v.7.0.9.0, to determine a preliminary haplogroup. Twenty-seven informative Single Nucleotid Polymorphisms (SNPs) on the coding region (positions 10873, 13276, 13789, 13470, 10810, 12950, 3594, 13710, 10400, 9818, 11899, 12049, 14088, 13485, 14034, 13803, 15939, 4158, 3693, 13958, 10086, 8618, 14905, 4218, $2352,750,7851)$ were typed by minisequencing SNaP$\operatorname{shot}^{\circ}$ (PE, Applied Biosystems). All data were obtained on an ABI PRISM 3730 sequencer (PE, Applied Biosystems). The final haplogroup assignment was obtained by the most recent mtDNA phylogeny [10].

\section{Y-Chromosome}

NRY were determined by two types of markers. Seventeen Short tandem repeats (STRs) were typed using the AmpFLSTR Yfiler kit (PE, Applied Biosystems). Twentyfour Unique Event polymorphisms (UEPs; SRY 10831,
M213, M9, M70, M22, Tat, 92R7, M173, P25, M96, M35, M78, M81, M123, M34, M17, M18, M73, M37, M63, M126, M153, M160, SRY 2627) were typed following the protocol published previously [20]. An additional set of nine UEPs (M33, U174, M191, M75, U209, M2, P2, M91, M60) has been designed to precise the haplogroup assignment. All data were read on an ABI PRISM 3730 sequencer and analysed with Genemapper v.4.0 (PE, Applied Biosystems). The YAP analysis has been obtained following Hammer and Horai [21]. The haplogroup assignment follows the most recently updated NRY phylogeny [9].

HTLV-1

The overall HTLV-I seroprevalence in the Noir Marron population in French Guiana is about 6\% in women and $4 \%$ in men [13,22-25]. Determination of HTLV-1 genomic subtype in env and LTR regions, which are used as markers of the migration of infected populations, was performed for 23 samples of HTLV-1 infected Noir Marron individuals representative of the main Noir 
Marron communities: Saramaka $(\mathrm{n}=6)$, Ndjuka $(\mathrm{n}=6)$, Aluku $(\mathrm{n}=5)$ and Paramaka $(\mathrm{n}=6)$ (Genbank accession number: GU725032-GU725054) and compared with the corresponding database available in Genbank.

High molecular-weight DNA was extracted from peripheral blood buffy-coats using the QIAamp DNA Blood Mini Kit (Qiagen GmbH, Hilden, Germany). All samples were firstly determined to contain amplifiable DNA after being amplified by PCR for human $\beta$-globin. Five hundred nanograms, quantified by spectrophotometry, of each DNA sample was then subjected to two series of PCR to obtain the complete long terminal repeat (LTR) (755-bp) and a 522-bp region of the env gene, as previously described $[26,27]$. To prevent false-positive reactions, all pre- and post-PCR operations were performed in separate facilities. The complete LTR was obtained for eight individuals while the 522-bp Env fragment was obtained for the 23 samples tested. The amplified products of the appropriate size were cloned, sequenced and phylogenetically analysed as described [28,29].

\section{Data Analyses}

All summary statistics for mtDNA and NRY haplotype variation, Tajima's D and Fu's Fs tests were calculated using the ARLEQUIN 3.11 software package [17]. Four databases were compiled from published studies, updated with data from the African populations of Benin and Ivory Coast analysed in the present study. The African mtDNA database was composed of 170 populations representing 8727 HVS-I and 3500 HVS-II haplotypes associated with their corresponding haplogroup assignment. The African NRY database was composed of 145 populations representing 8909 individuals typed for UEP informative for the haplogroup assignment and 1200 Y-STR profiles. As the Y- SNP haplogroup information is lacking in some African regions, it was statistically inferred from the Y-STR data available, as previously explained [30]. For some analyses, the African databases were divided into nine groups according to their historical region of slavery described by H.S. Klein [1], the genetic coherence and published genetic studies [2,31]: North Africa (Algeria, Canary Island, Egypt, Mauritania, Morocco), Windward Coast, Senegambia and Sierra Leone (Cabo Verde, Guinee-Bissau, Mali, Senegal, Sierra Leone), Gold Coast and Bight of Benin (Benin, Burkina Faso, Ivory Coast), Bight of Biafra (Cameroon, Central African Republic, Chad, Equatorial Guinea, Gabon, Nigeria, Niger, Sao Tome), South West Africa (Angola, Cabinda, Democratic Republic of Congo), South Africa (Botswana, Malawi, Namibia, Zambia, Zimbabwe), South East Africa (Mozambique), East Africa (Ethiopia, Kenya, Rwanda, Somalia, Uganda, Sudan, Tanzania), and Pygmies. The mtDNA and NRY databases of African
American and urban hybridised populations were composed of 95 and 90 populations, respectively. Due to the heterogeneous resolution of haplogroup assignment among populations, forming a non-relevant database, only the admixture rates of continental populations (European, Amerindian and African), given in published studies, have been considered. Despite this bias, as African ancestry is relatively common in all African Americans [1,32], their discrimination is mostly due to differential contribution of non-African gene pools. All populations considered in the present study are located on Figure 2 and complete references are available in Additional file 1.

Haplotype networks were generated for mtDNA haplogroups L2a* and L1c*, and for the NRY haplogroup E1b1a* via the median-joining algorithm of Network v.4.5.1.6 http://www.fluxus-engineering.com from the Noir Marron data and all African and African American comparable data. To obtain the most parsimonious networks the reticulation permissivity was set to zero. Data were pre-processed using the star contraction option in Network v.4.5.1.6 [33]. For the mtDNA data, hypermutable sites were identified by post-processing using the Steiner (MP) algorithm within Network 4.5.1.6, and removed from the analysis [34]. Because of the high level of reticulation in the E1b1a* sample, Y-STR loci were subdivided into three mutation rate classes based on observed STR allelic variance and weighted as follows: 4 (low) for DYS391, DYS392; 2 (intermediate) for DYS389I, DYS389II, DYS19, DYS393, DYS390; or 1 (high) for DYS385a/b [35].

Cross-population comparisons of maternal and paternal lineages based on the frequency of haplogroups or rates of continental ancestry common to all samples in the database were performed using ARLEQUIN 3.11 [17]. The significance of Fst values is given for p-values under a threshold of 0.05. All results obtained for the comparison between the Noir Marron and each population of the database were graphically plotted on a map using Surfer v.8.0, using the location of each population given in the corresponding study. Factorial Correspondence Analysis (FCA) based on mtDNA and Y-chromosome haplogroup frequencies were performed using XLstat v.7.5.2. Analyses of molecular variance (AMOVA) were performed with ARLEQUIN 3.11 [17]. Admixture estimates were calculated by two different methods. The first, based on haplotypic homology (up to $99 \%$ of homology), was calculated by the percentage of shared lineages (LS) between the Noir Marron and each compared group [36]. Haplotype comparisons were performed from HVS-I mtDNA sequences (1603016360) and NRY core haplotypes (DYS19, DYS389I, DYS389II, DYS390, DYS391, DYS392, DYS393, DYS385a/b) to obtain the most relevant results from the 
compiled databases. The second estimator, $m Y$, was calculated with the ADMIX2.0 program [37]. Both mtDNA-based and NRY-based estimates were calculated from haplogroup frequencies without taking into account molecular distances between haplogroups. The parental populations were chosen among the groups that presented a Fst value, obtained by the AMOVA for the comparison with the Noir Marron, lower than an threshold fixed at 0.1 .

Concerning HTLV-1 Env and LTR phylogenetic analysis, the phylogenetic trees were generated using the Neighbor-Joining method performed in the PAUP v.4.0b10 program using representative HTLV-1 sequences available in Genbank, including four env sequences and one LTR sequence typed in Noir Marron individuals of French Guiana [13]. The strains were aligned with the DAMBE v.4.2.13 program and the final alignment was submitted to the Modeltest v. 3.6 program to select, according to the Akaike Information Criterion (AIC), the best model to apply to phylogenetic analyses. Confidence levels were estimated with the distance NJBOOT program (1,000 replicates).

\section{Results mtDNA \\ Genetic diversity}

A total of 78 different mtDNA haplotypes were characterised among the 142 Noir Marron individuals (GenBank accession number: GU807605 - GU808086; Additional file 2). Statistics estimating the sequence diversity were relatively high $(\mathrm{H}=0.988 \pm 0.003 ; \pi=$ $0.019 \pm 0.009 ; \theta \mathrm{k}=72.859$; Table 1 ) and within the range found in other African American groups and SubSaharan populations [32,38]. Although the Fu's test is not significant $(\mathrm{Fs}=-23.987(0.001)$; Table 1$)$, this diversity is correlated with a significant value obtained for Tajima's test, revealing a population expansion ( $\mathrm{D}=$ -0.549 (0.357); Table 1). Considering the differences between the number of individuals in each Noir Marron community, all results are relatively similar.

All mtDNA haplotypes were phylogenetically identified following the latest classification [10]. 99.3\% of them belonged to the major African haplogroup L* (Additional file 2). The highest percentages were observed for L2a* (22.5\%) and L1c (19.0\%), which are widely present in Africa [31]. Phylogenetic trees of these sub-haplogroups show no Noir Marron founder haplotype, but an integration of all haplotypes within the African and African American diversity (Figure 3). The sub-divisions L2a1 (14.1\%) and L1c1 (12.7\%) were found more in West African populations [31]. This West African link was also suggested by the presence of L1b (14.1\%), L3e2 (7.0\%), L3d (3.5\%) and L3f1 (3.5\%). Other L sub-haplogroups are more widely found in Africa but present low frequencies in the Noir Marron sample. A unique European haplogroup was observed through the characterization of U5b1c, which is present in the South of Europe [39]. With the aim to evaluate the maternal contribution of Africans, Europeans and Amerindians, the mtDNA admixture ratio was calculated following the geographical origin of each haplogroup. It revealed an African contribution of $99.3 \%$ and a European contribution of $0.7 \%$, whereas no Amerindian contribution was detectable.

\section{Population cross-comparisons}

The maternal genetic diversity of the Noir Marron was compared to other American African and African communities using a population pairwise Fst comparison. All Fst values obtained are plotted graphically on Figure 4 . Among the 95 African American and American urban groups, only 24 presented low differentiations with the Noir Marron (Fst < 0.05). The majority inhabit the United States, especially the East Coast [6,40-43]. The remaining populations are the Garifunas in Belize [44], some English-speaking Caribbean groups such as $\mathrm{St}$ Kitts, St Vincent and St Lucia [45], Afro-Venezuelians in Curiepe [5] and the black communities of Porto Alegre, Rio de Janeiro in Brazil $[46,47]$. The 71 maternal lineages of other African American or urban hybridised communities were highly different from the Noir Marron (Fst > 0.25 ), such as the neighbouring Afro-Brazilian groups, notably due to their Amerindian ancestry [5,47-51].

Thus, the mtDNA pattern of the Noir Marron is closer to that of Africans than of most African Americans. This maternal African ancestry showed a low divergence with $41 \%$ of African groups (Fst < 0.05). Many of them are located in West Africa and South West Africa, such as Senegal [52], Cabo Verde [53], Sierra Leone [54], Guinea-Bissau [55], Mali [41], Ivory Coast (present study), Burkina Faso [56], Benin [57] (present study), Niger [56], Cameroon [58-63], Chad [59], Gabon [62], Equatorial Guinea [64], Angola [65] and Cabinda [66]. However, inside this large area, three clusters of high genetic divergence from the mtDNA gene pool were observed identifying the Pygmy communities of Cameroon [61,62], Gabon [62] and Central African Republic $[63,67]$, the Fang from Equatorial Guinea [68] and the Mbuti from the Democratic Republic of Congo [69]. High divergences were also present in North African, East African, South East African and South African populations, even though some groups have low differences, as one Somalian population [56], one Sudanese population [70], one Namibian population [63], one Rwandan group [71] and three Bantu-speaking groups located in the Democratic Republic of Congo [69], Uganda [72] and Kenya [56].

A Factorial Correspondence Analysis (FCA) was realised to look at the mitochondrial relationships between 
Table 1 Summary statistics estimating the mtDNA genetic diversity of the Noir Marron.

\begin{tabular}{|c|c|c|c|c|c|c|c|c|}
\hline Population & $\mathrm{N}$ & k & $\begin{array}{c}\mathrm{H} \\
\text { (SD) }\end{array}$ & $\begin{array}{c}\mathbf{\theta k} \\
(95 \% \mathrm{Cl}) \\
\end{array}$ & $\begin{array}{c}\theta s \\
\text { (SD) }\end{array}$ & $\begin{array}{c}\pi \\
\text { (SD) }\end{array}$ & $\begin{array}{c}\text { Tajima's D } \\
\text { (P) }\end{array}$ & $\begin{array}{l}\text { Fu's Fs } \\
\text { (P) }\end{array}$ \\
\hline Aluku & 10 & 9 & $\begin{array}{c}0.977 \\
( \pm 0.054)\end{array}$ & $\begin{array}{c}38.775 \\
(9.402-169.084)\end{array}$ & $\begin{array}{c}15.553 \\
( \pm 6.606)\end{array}$ & $\begin{array}{c}0.019 \\
( \pm 0.010)\end{array}$ & $\begin{array}{l}-0.075 \\
(0.494)\end{array}$ & $\begin{array}{l}-0.693 \\
(0.302)\end{array}$ \\
\hline Ndjuka & 80 & 50 & $\begin{array}{c}0.983 \\
( \pm 0.006)\end{array}$ & $\begin{array}{c}60.691 \\
(38.367-96.897)\end{array}$ & $\begin{array}{c}17.499 \\
( \pm 4.766)\end{array}$ & $\begin{array}{c}0.019 \\
( \pm 0.009)\end{array}$ & $\begin{array}{l}-0.549 \\
(0.357)\end{array}$ & $\begin{array}{r}-17.139 \\
(0.001)\end{array}$ \\
\hline Paramaka & 11 & 7 & $\begin{array}{c}0.911 \\
( \pm 0.077)\end{array}$ & $\begin{array}{c}9.023 \\
(2.907-29.191)\end{array}$ & $\begin{array}{c}14.846 \\
( \pm 6.322)\end{array}$ & $\begin{array}{c}0.019 \\
( \pm 0.011)\end{array}$ & $\begin{array}{c}0.145 \\
(0.620)\end{array}$ & $\begin{array}{c}1.899 \\
(0.820)\end{array}$ \\
\hline Saramaka & 41 & 23 & $\begin{array}{c}0.975 \\
( \pm 0.013) \\
\end{array}$ & $\begin{array}{c}28.055 \\
(14.525-55.171) \\
\end{array}$ & $\begin{array}{c}16.512 \\
( \pm 5.232) \\
\end{array}$ & $\begin{array}{c}0.020 \\
( \pm 0.010) \\
\end{array}$ & $\begin{array}{l}-0.084 \\
(0.538) \\
\end{array}$ & $\begin{array}{l}-2.178 \\
(0.236) \\
\end{array}$ \\
\hline Total Noir Marron & 142 & 78 & $\begin{array}{c}0.988 \\
( \pm 0.003)\end{array}$ & $\begin{array}{c}72.859 \\
(51.408-103.439)\end{array}$ & $\begin{array}{c}18.668 \\
( \pm 0.622)\end{array}$ & $\begin{array}{c}0.019 \\
( \pm 0.009)\end{array}$ & $\begin{array}{l}-0.549 \\
(0.357)\end{array}$ & $\begin{array}{r}-23.987 \\
(0.001)\end{array}$ \\
\hline
\end{tabular}

$\mathrm{N}$ : number of sequences; $\mathrm{k}$ : number of different haplotypes; $\mathrm{H}$ : Haplotype diversity; $\theta$ : mutation drift statistic calculated from the number of different haplotypes $(\theta k)$ and segregating sites $(\theta s) ; \pi$ : nucleotide diversity.

the Noir Marron and 170 African populations (Figure 5). $40.6 \%$ of the genetic variance is represented by Factors 1 and 2. The haplogroups M-N-R, L1c and LOa contribute significantly (contribution $>5 \%$ ) to Axis 1 and haplogroups L0a and L1c to Axis 2 (contribution $>5 \%$ ). The Noir Marron are clustered in West African and South West African populations historically enslaved, whereas North Africans, South Africans, East Africans and populations from South East Africa are peripheral to this group. This result is consistent with the results of the population pairwise Fst comparison.

An AMOVA based on the clustering of African populations by historical regions of slavery and genetic coherence showed that $10.4 \%$ of the variance lies between groups, $11.1 \%$ among populations within groups and $78.6 \%$ within populations ( $\mathrm{p}$ values $<0.01$; Additional file 3). Despite this low significance, high values were found between the Noir Marron and the East Africans, South Africans, North Africans and
Pygmies $(0.13 \leq$ Fst $\leq 0.26)$, whereas they seem to be genetically closer to populations in the groups "Windward Coast, Senegambia and Sierra Leone", "Gold Coast and Bight of Benin", "Bight of Biafra", "South West Africa" and "South East Africa" (Fst $\leq 0.07$, Table 2).

\section{Admixture analysis}

All mtDNA data of the five African groups presenting Fst values lower than the chosen threshold (Fst $<0.1$ ) were used to evaluate the maternal African admixture percentage of the Noir Marron community (Table 2). Both estimators, LS and $m Y$ rates, identify a major origin in the "Gold Coast and Bight of Benin" (LS $=29 \%$; $\mathrm{mY}=64 \%)$. Two other important ancestries are detected in "South West Africa" (LS $=26 \%$; $\mathrm{mY}=$ $23 \%$ ) and in the "Bight of Biafra" (LS $=19 \%$; $\mathrm{mY}=$ 13\%). The two last regions present lower probabilities of ancestry: "Windward Coast, Senegambia and Sierra Leone" (LS $=13 \% ; \mathrm{mY}=0 \%)$ and "South East Africa" $(\mathrm{LS}=14 \% ; \mathrm{mY}=0 \%)$.

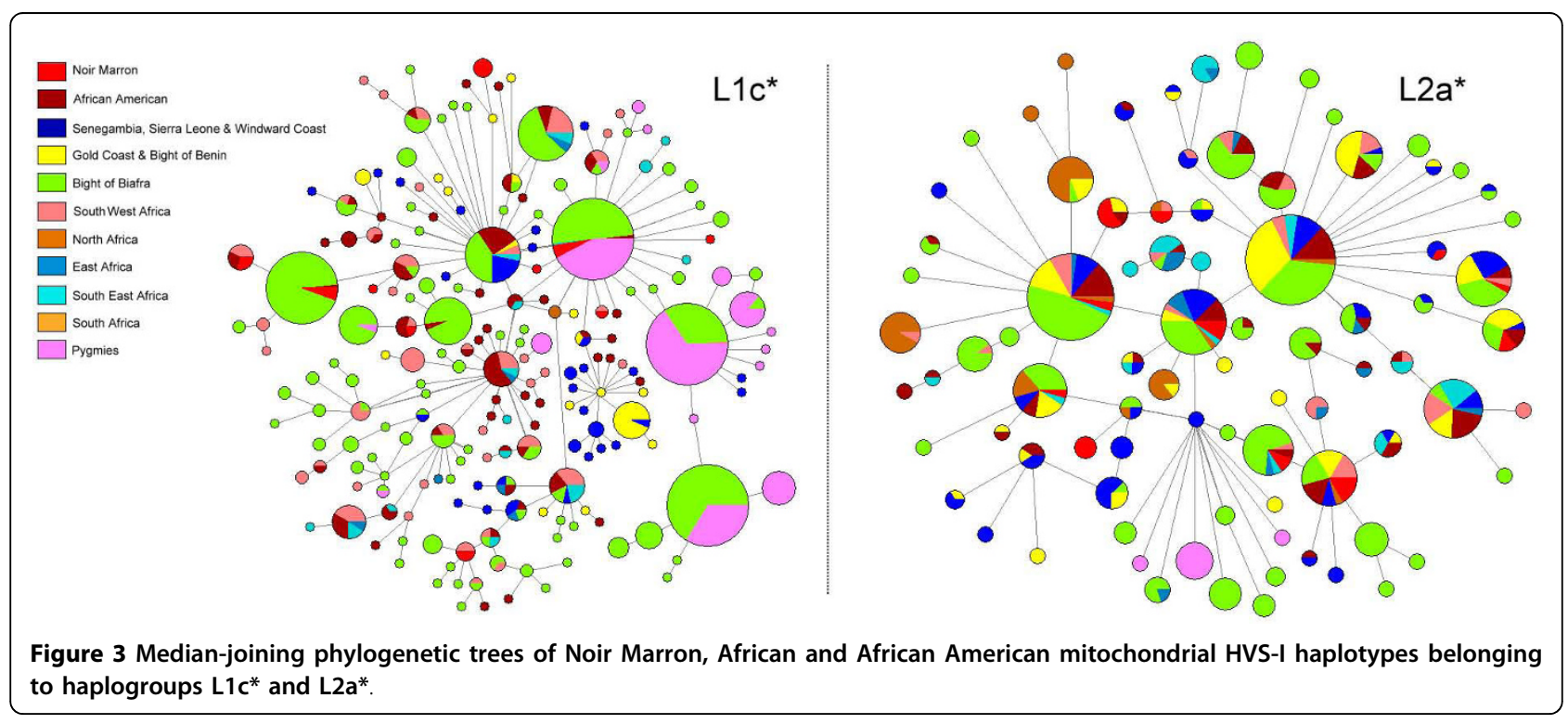




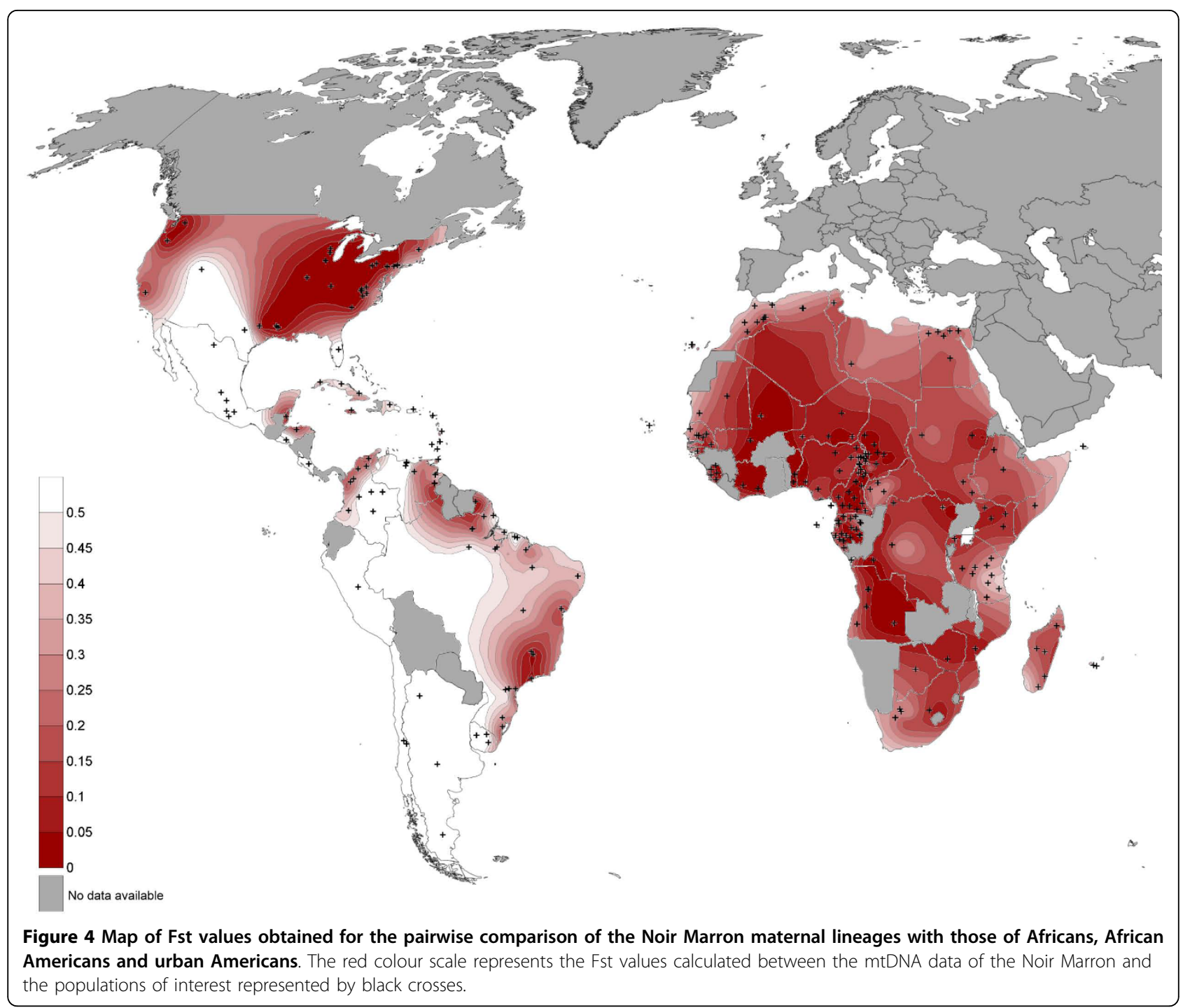

\section{Y-Chromosome}

\section{Genetic diversity}

Among the 42 Noir Marron typed for NRY, 36 different haplotypes were detected (YHRD accession Number YA003610-YA003615; Additional file 4). The genetic diversity shows a high-level $(\mathrm{H}=0.990 \pm 0.008)$, similar to that found in other African American groups and Sub-Saharan populations [73]. All haplotypes were grouped using the latest NRY phylogeny [9]. 90.5\% belong to the major African haplogroup E1b1* with notably $88 \%$ of the sub-division E1b1a*, which is more frequent in West Africa [74]. The phylogenetic tree of this sub-haplogroup shows no Noir Marron founder haplotype, but an integration of all haplotypes within the African and African American diversity (Figure 6). Three occurrences of African haplogroups A and B, more frequent in South West Africa and South Africa, especially in Pygmy and Khoisan populations, were detected $[9,75]$. One individual was positively typed for the R1b sub-haplogroup which is as frequent in Europe as in Cameroon [76,77]. The probable continental paternal ancestry was estimated following the geographical origin of each haplogroup. It shows an African contribution of $97.6 \%$, a European contribution of $2.4 \%$ and no Amerindian origin.

\section{Population cross-comparisons}

As for the maternal lineage, the paternal gene pool of the Noir Marron was compared to those of other African Americans and Africans (Figure 7). Only three of the 90 African Americans showed low Fst values (Fst < 0.05): a community from Illinois [78] and Baltimore in United States [43], and one from Ribeirão Preto in Brazil [5]. All others presented significant differentiation from the Noir Marron. Moreover, Fst values exceeded 0.5 in 47 of them, due to their European inheritance, for example the African Americans of North East Brazil 


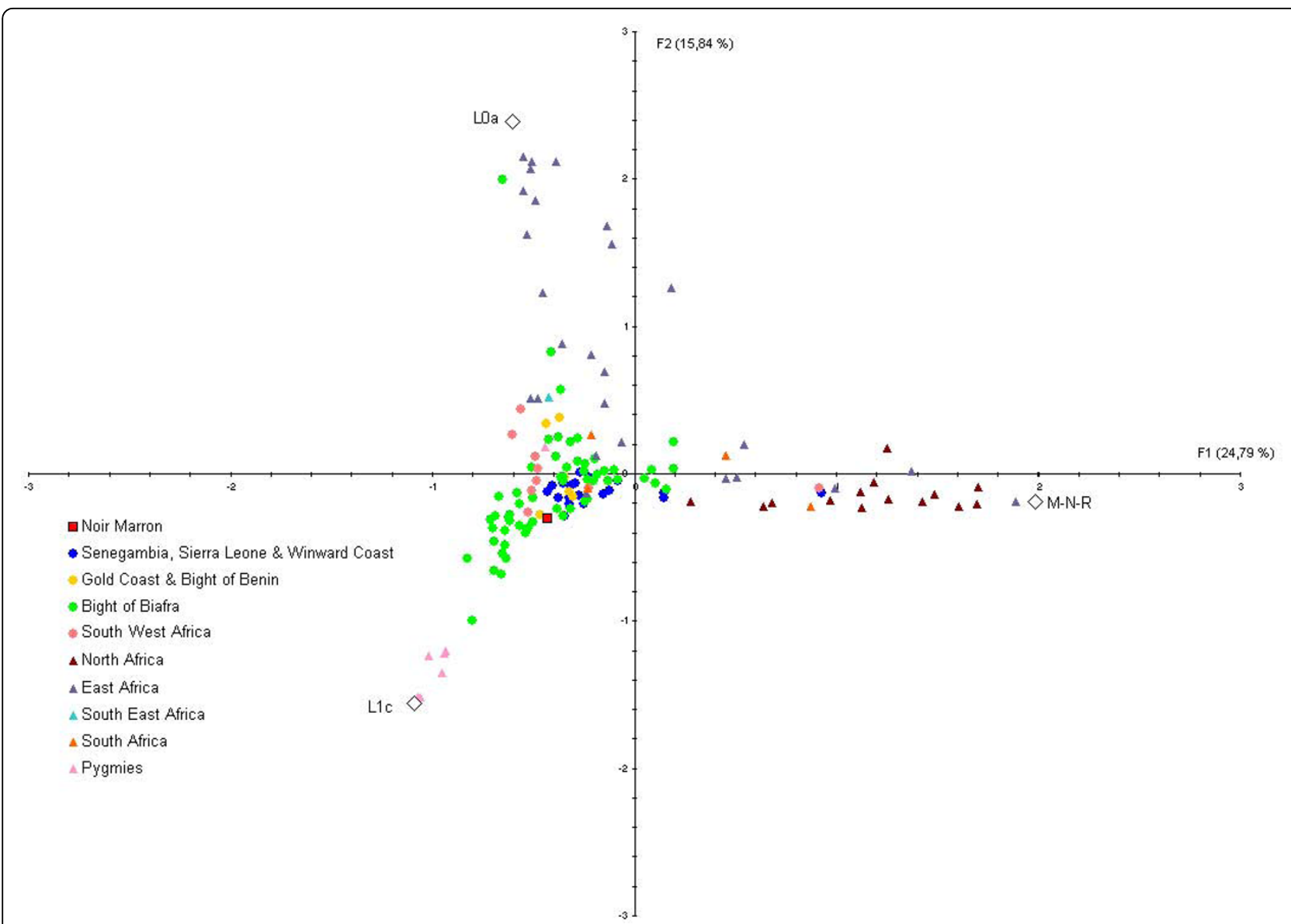

Figure 5 Plot showing the $1^{\text {st }}$ and $2^{\text {nd }}$ principal component of the FCA computed from the mtDNA haplogroup frequencies of the Noir Marron and African populations. Square point represents the Noir Marron population, circle points the West African and South West African populations, and all other groups are represented by triangular points. The colours identify the groups considered in the present study.

[5,48,79-81]. The preserved African ancestry of the Noir Marron paternal lineage leads them to be genetically closer to African groups.

The NRY gene pool of the Noir Marron showed low Fst values with only $10 \%$ of the African groups; the majority located in the Ivory Coast (present study),
Ghana [82], Benin (present study) and in Cameroon $[82,83]$, and with one from Gabon [77], Angola [66], Namibia [82], Zimbabwe [82] and South Africa [82]. The other groups: North Africans, East Africans, South East Africans, Pygmies [76,77,82] and other South Africans, notably the Khoisan groups [76,82], presented high

Table 2 Estimators of shared maternal ancestries of the Noir Marron

\begin{tabular}{|c|c|c|c|c|c|c|c|c|c|}
\hline & $\begin{array}{c}\text { Windward Coast, } \\
\text { Senegambia and Sierra } \\
\text { Leone }\end{array}$ & $\begin{array}{c}\text { Gold Coast } \\
\text { Bight of Benin }\end{array}$ & $\begin{array}{c}\text { Bight of } \\
\text { Biafra }\end{array}$ & $\begin{array}{l}\text { South } \\
\text { West } \\
\text { Africa }\end{array}$ & $\begin{array}{l}\text { North } \\
\text { Africa }\end{array}$ & $\begin{array}{c}\text { East } \\
\text { Africa }\end{array}$ & $\begin{array}{c}\text { South } \\
\text { East Africa }\end{array}$ & $\begin{array}{l}\text { South } \\
\text { Africa }\end{array}$ & Pygmies \\
\hline $\begin{array}{c}\mathrm{N} \text { pop } \\
\text { ( } \mathrm{N} \text { indiv) }\end{array}$ & $\begin{array}{c}20 \\
(1604)\end{array}$ & $\begin{array}{c}7 \\
(440)\end{array}$ & $\begin{array}{c}60 \\
(2361)\end{array}$ & $\begin{array}{c}9 \\
(625)\end{array}$ & $\begin{array}{c}18 \\
(1223)\end{array}$ & $\begin{array}{c}33 \\
(1365)\end{array}$ & $\begin{array}{c}10 \\
(425)\end{array}$ & $\begin{array}{c}5 \\
(165)\end{array}$ & $\begin{array}{c}8 \\
(519)\end{array}$ \\
\hline $\begin{array}{c}\text { Fst (versus Noir } \\
\text { Marron) }\end{array}$ & 0.03 & 0.03 & 0.07 & 0.06 & 0.26 & 0.13 & 0.07 & 0.14 & 0.23 \\
\hline $\begin{array}{l}\text { Shared } \\
\text { Lineages rate } \\
(\mathrm{LS})\end{array}$ & 0.13 & 0.29 & 0.19 & 0.26 & - & - & 0.14 & - & - \\
\hline $\begin{array}{l}\text { Admixture } \\
\text { rate }(\mathrm{mY})\end{array}$ & $0( \pm 0.17)$ & $0.64( \pm 0.20)$ & $0.13( \pm 0.16)$ & $0.23( \pm 0.17)$ & - & - & $0( \pm 0.18)$ & - & - \\
\hline
\end{tabular}

Estimates and standard deviations (shown between parentheses) were computed from 1000 bootstraps replications. $\mathrm{N}$ indiv: number of individuals; $\mathrm{N}$ pop: number of populations; LS: Shared Lineages analysis (see [36]); $m Y$ : estimator of admixture (see [37]); dashes represent groups that were not included in the calculation of ancestry. 


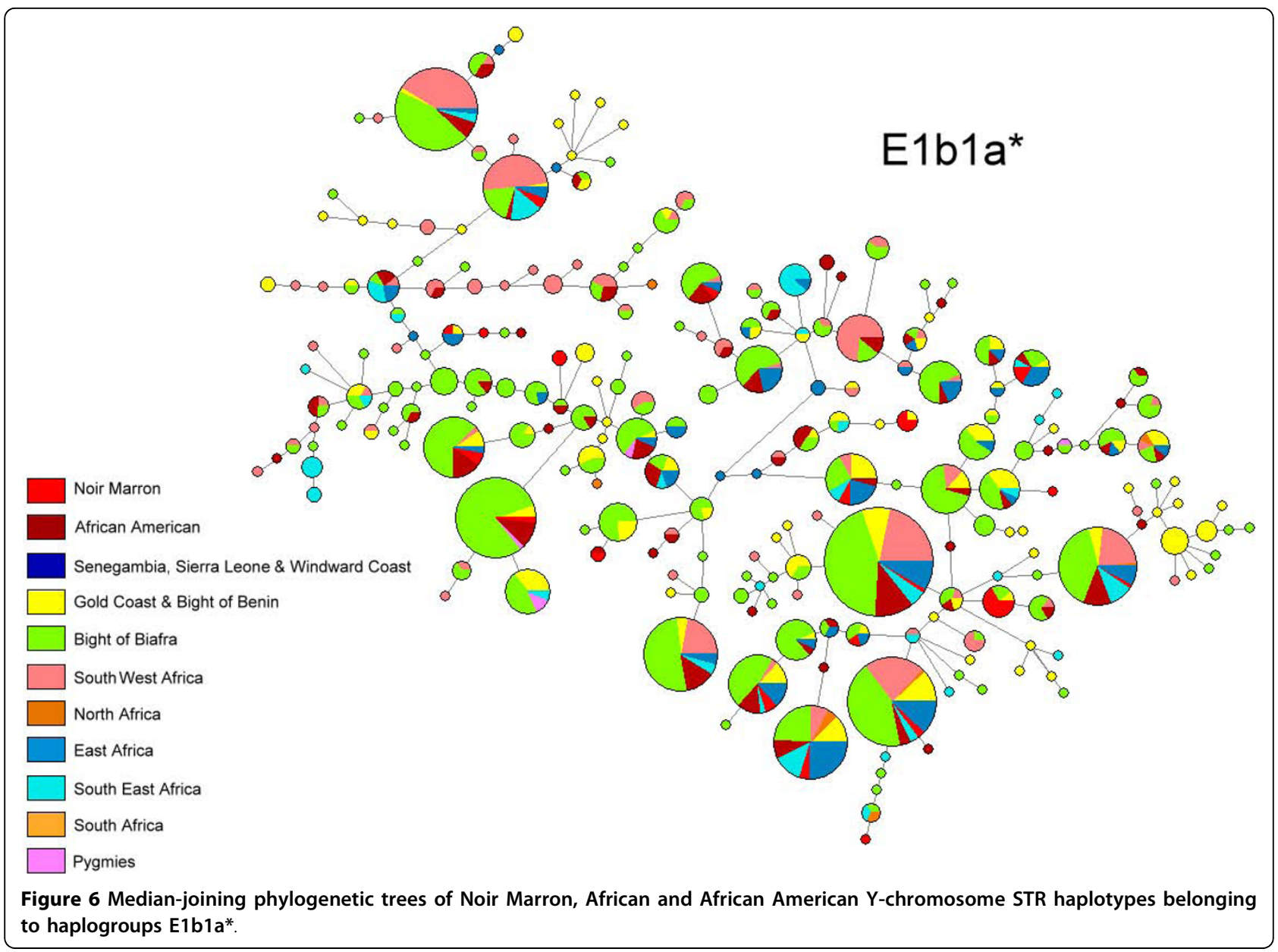

divergence (Fst $>0.25)$. The paternal ancestry of the Noir Marron is observed to be less widespread than the maternal ancestry.

A FCA was computed to plot the Noir Marron and African genetic NRY diversity (Figure 8). A total of $25.4 \%$ of the variance is represented on Axis 1 and 2. The haplogroups G-H-K-R, E1b1b1b, E1b1b1a, E1b1a and IJ contribute significantly to Axis 1 (contribution $>5 \%)$ and haplogroups $\mathrm{E}^{*}, \mathrm{E} 1 \mathrm{~b} 1 \mathrm{a}, \mathrm{E} 1 \mathrm{~b} 1, \mathrm{CF}$, E1b1b1b and E1b1b1 to Axis 2 (contribution $>5 \%$ ). As observed for mtDNA, the Noir Marron are clustered in a group composed predominantly of West African and South West African populations, while other African populations are peripheral to this group.

The clustering of African populations by historical regions of slavery showed no genetic significance, due to the low genetic divergence between West African groups, as suggested by previous studies on NRY data $[76,77]$. Ten percent of the variance lies between groups, $25.7 \%$ among populations within groups, and $64.3 \%$ within populations ( $\mathrm{p}$ values $<0.01$; Additional file 3 ). However, confirming the results of the population pairwise Fst comparison, the lowest values were obtained between the Noir Marron and "Gold Coast and Bight of Benin", "Windward Coast, Senegambia and Sierra Leone", "Bight of Biafra", "South West Africa" and "South Africa" (Fst $\leq 0.08$; Table 3).

\section{Admixture analysis}

All NRY data of the five African groups presenting Fst values lower than the chosen threshold (Fst $<0.1)$ were used to evaluate the paternal African admixture percentage of the Noir Marron community (Table 3). As for mtDNA analysies, both estimators, LS and $m Y$ rates, identify a major origin in the "Gold Coast and Bight of Benin" ( $\mathrm{LS}=28 \%$; $\mathrm{mY}=74 \%$ ). One other non negligible ancestry is located in "Windward Coast, Senegambia and Sierra Leone" (LS $=25 \%$; $\mathrm{mY}=26 \%$ ). The remaining regions show lower probabilities of ancestry: "Bight of Biafra" (LS $=19 \%$; $\mathrm{mY}=0 \%$ ) "South West Africa" $(\mathrm{LS}=13 \% ; \mathrm{mY}=0 \%)$.

\section{HTLV-1}

\section{Sequence analysis}

The analysis of the env 522-bp fragments of the 23 new HTLV-1 Noir Marron strains indicated neither deletion 


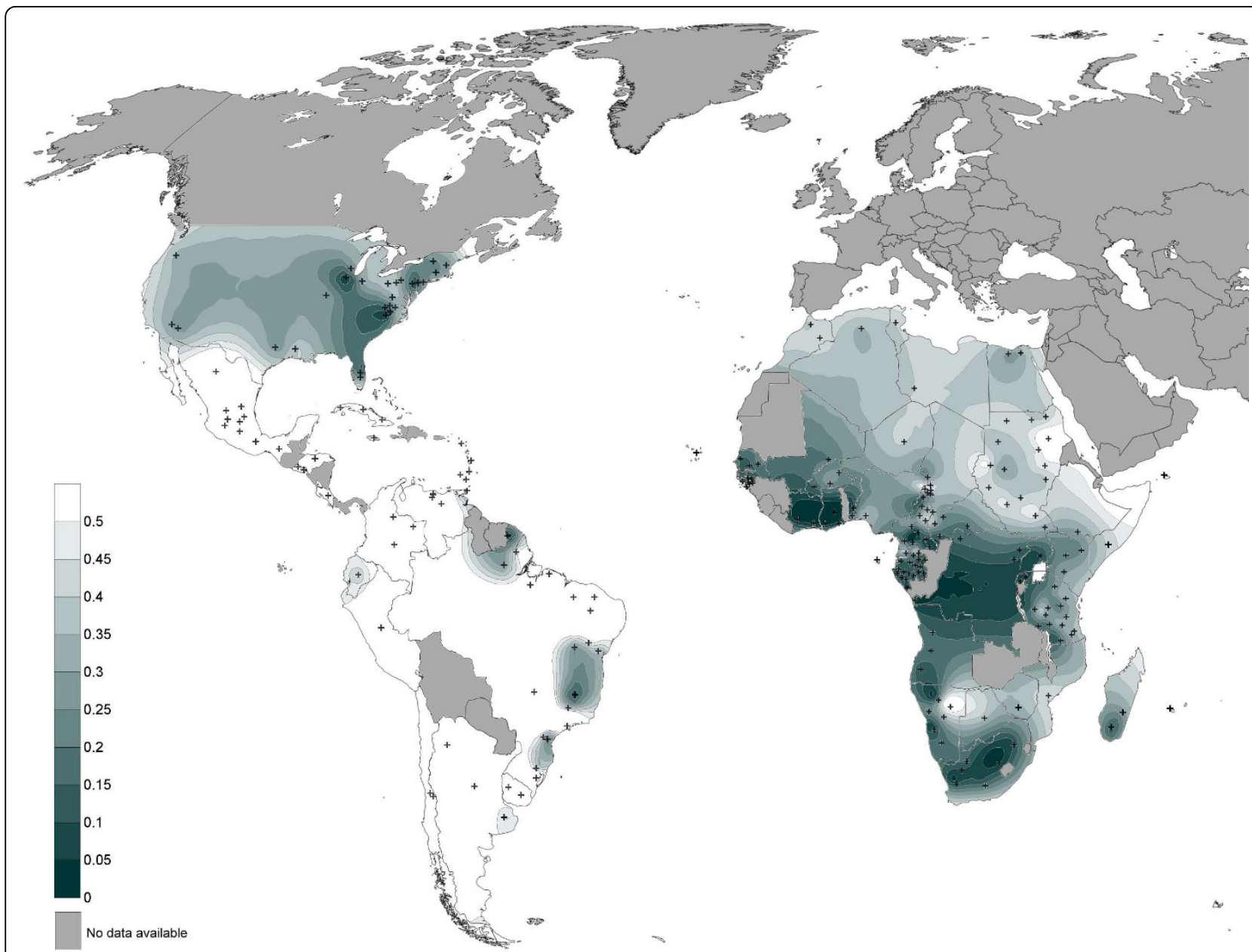

Figure 7 Map of Fst values obtained for the pairwise comparison of the Noir Marron paternal lineages with those of Africans, African Americans and urban Americans. The green colour scale represents the Fst values calculated between the NRY data of the Noir Marron and the populations of interest, which are represented by black crosses.

nor insertion compared with the ATK-1 reference strain. Comparison of the 23 strains indicated that four sequences and two pairs were identical. All together, the 23 strains showed a nucleotidic interstrain difference ranging from $0-1.5 \%$ and an amino acid divergence ranging from $0-1.7 \%$. Nevertheless, 17 strains were closely related with $0-0.8 \%$ of nucleotide differences on 522 nucleotides and $0-1.7 \%$ at the amino acid level.

In parallel, LTR sequences obtained from eight representative individuals of the four Noir Marron communities: Saramaka (2), Ndjuka (2), Aluku (2) and Paramaka (2) were analysed and exhibited 0-2.4\% divergence at the nucleotide level. Interestingly, six strains were closely related with only $0-0.7 \%$ nucleotidic divergence for the 757-bp LTR fragment.

\section{Phylogenetic analysis}

Phylogenetic analyses were performed comparing these 23 new sequences with 70 representatives e $n v$ gene sequences available in GenBank of the HTLV-1
Cosmopolitan A subtype, as well as sequences obtained from individuals originating from Melanesian $C$ subtype, used as an outgroup (Figure 9). Firstly, all sequences belonged to the large cosmopolitan subtype and none were related to other subtypes, especially other African ones (B or D), which are mainly found in Central Africa (data not shown). Secondly, among the 23 Noir Marron HTLV-1 env strains, 17 clustered in the same large "West Africa" subgroup, clustering strains from Senegal, Burkina Faso and Ivory Coast. Three strains (1602, 2002 and 4702) constitute a cluster related to strains originating from Mali, Burkina-Faso, Guinea-Bissau, Senegal and Mauritania, while the remaining three (4502, 7202 and 6101) were related to South American strains from Peru, Surinam and Guyana. Worth noting is that most of the LTR sequences (6/8) analysed belonged to the "West Africa" subgroup, while the remaining two clustered in the "Transcontinental" subgroup (Additional file 5). 


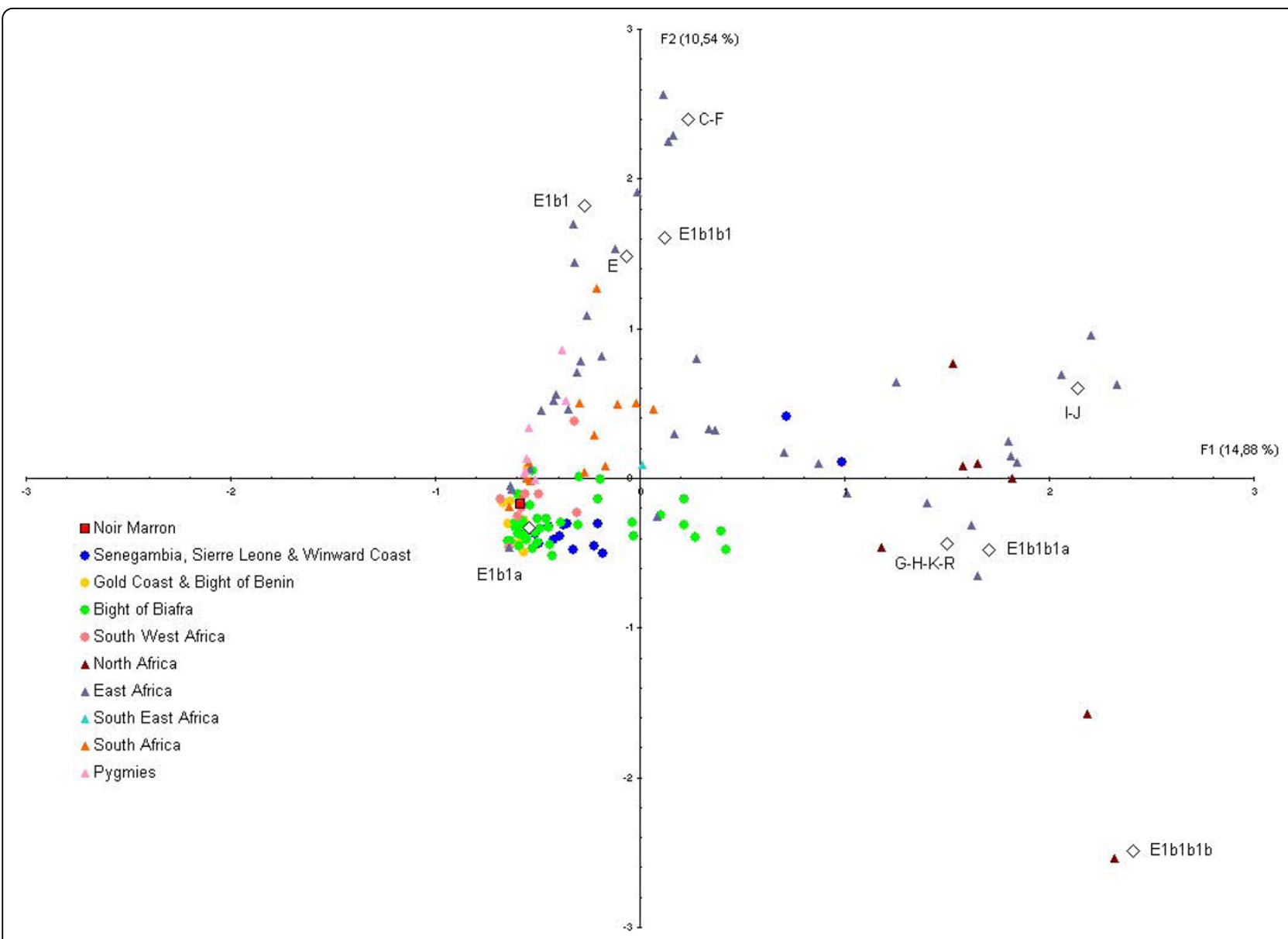

Figure 8 Plot showing the $1^{\text {st }}$ and $2^{\text {nd }}$ principal component of the FCA computed from the NRY haplogroup frequencies of the Noir Marron and African populations. Square point represents the Noir Marron population, circle points the West African and South West African populations, and all other groups are represented by triangular points. The colours identify the groups considered in the present study.

\section{Discussion}

\section{An original African American population}

The African American community is composed of highly diverse ethnic groups in terms of their historical, cultural and biological inheritances. Each of them has their specific identity. Being one of the last known
American maroon community, the Noir Marron are an important part this diversity [3]. A previous analysis of the $\mathrm{Gm}$ system showed their preserved African gene pool $(>95 \%)$, revealing a first insight into their genetic originality in comparison with other neighbouring African American groups [7]. The present study, exploring

Table 3 Estimators of shared paternal ancestries of the Noir Marron.

\begin{tabular}{|c|c|c|c|c|c|c|c|c|c|}
\hline & $\begin{array}{c}\text { Windward Coast, } \\
\text { Senegambia and Sierra } \\
\text { Leone }\end{array}$ & $\begin{array}{c}\text { Gold Coast } \\
\text { Bight of Benin }\end{array}$ & $\begin{array}{c}\text { Bight of } \\
\text { Biafra }\end{array}$ & $\begin{array}{c}\text { South West } \\
\text { Africa }\end{array}$ & $\begin{array}{l}\text { North } \\
\text { Africa }\end{array}$ & $\begin{array}{c}\text { East } \\
\text { Africa }\end{array}$ & $\begin{array}{c}\text { South East } \\
\text { Africa }\end{array}$ & $\begin{array}{l}\text { South } \\
\text { Africa }\end{array}$ & Pygmies \\
\hline $\begin{array}{c}\mathrm{N} \text { pop } \\
\text { (N indiv) }\end{array}$ & $\begin{array}{c}13 \\
(182)\end{array}$ & $\begin{array}{c}10 \\
(197)\end{array}$ & $\begin{array}{c}42 \\
(1321)\end{array}$ & $\begin{array}{c}8 \\
(236)\end{array}$ & $\begin{array}{c}7 \\
(234)\end{array}$ & $\begin{array}{c}39 \\
(462)\end{array}$ & $\begin{array}{c}5 \\
(291)\end{array}$ & $\begin{array}{c}13 \\
(54)\end{array}$ & $\begin{array}{c}9 \\
(127)\end{array}$ \\
\hline $\begin{array}{c}\text { Fst (versus Noir } \\
\text { Marron) }\end{array}$ & 0.08 & 0.07 & 0.07 & 0.04 & 0.25 & 0.14 & 0.16 & 0.07 & 0.31 \\
\hline $\begin{array}{c}\text { Shared } \\
\text { Lineages rate } \\
\text { (LS) }\end{array}$ & 0.25 & 0.28 & 0.19 & 0.13 & - & - & - & 0.16 & - \\
\hline $\begin{array}{c}\text { Admixture rate } \\
(\mathrm{mY})\end{array}$ & $0.26( \pm 0.28)$ & $0.74( \pm 0.19)$ & $0( \pm 0.35)$ & $0( \pm 0.20)$ & - & - & - & $0( \pm 0.15)$ & - \\
\hline
\end{tabular}

Estimates and standard deviations (shown between parentheses) were computed from 1000 bootstraps replications. $\mathrm{N}$ indiv: number of individuals; $\mathrm{N}$ pop: number of populations; LS: Shared Lineages analysis (see [36]); $m Y$ : estimator of admixture (see [37]); dashes represent groups that were no included in the calculation of ancestry. 


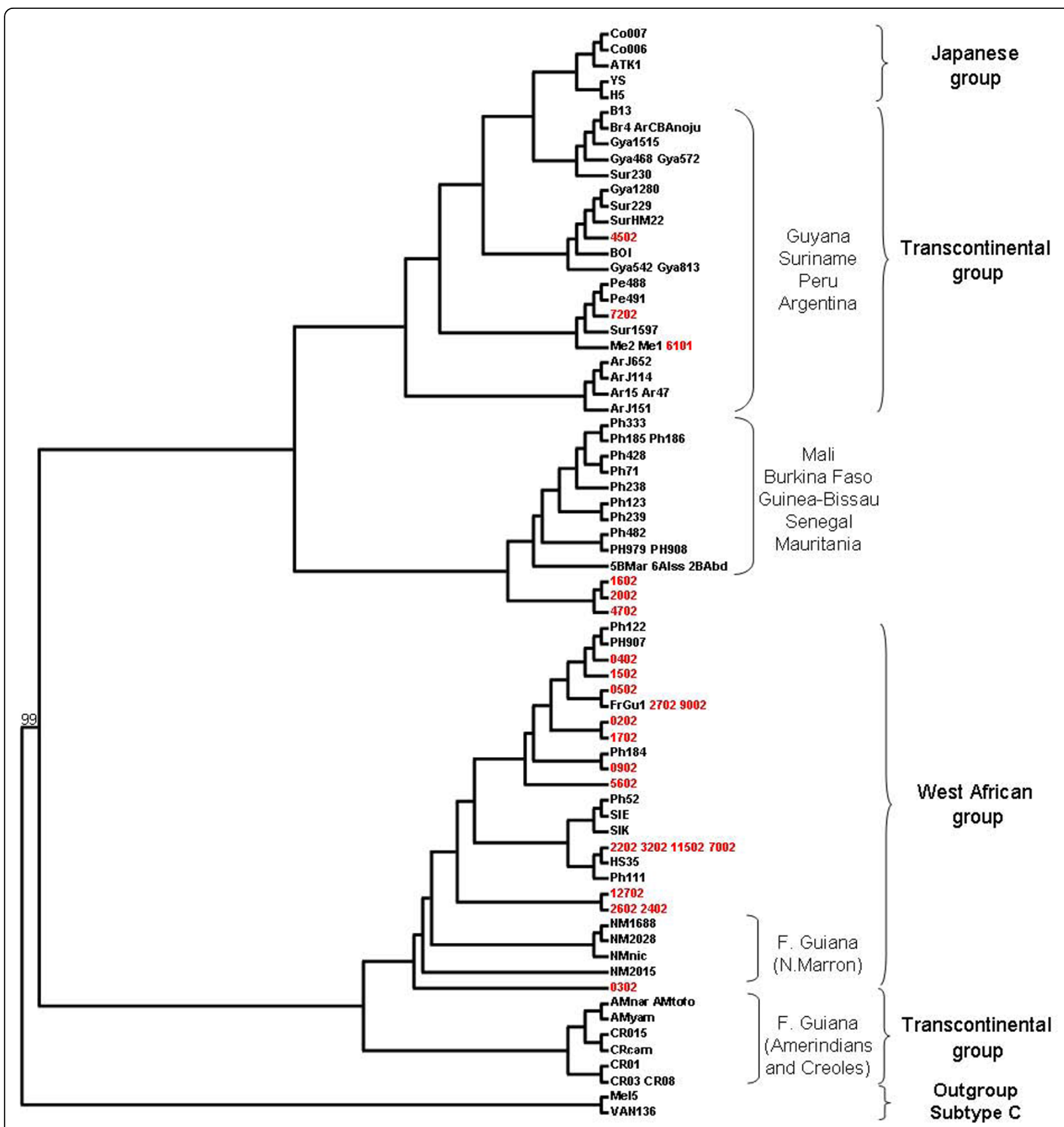

Figure 9 Env phylogenetic tree generated using the Neighbor-Joining method performed in the PAUP program (v4.0b10) on a 519-bp fragment of the Env gene using $\mathbf{7 5 ~ H T L V - 1}$ available sequences available in Genbank. The new Noir Marron data are coded in red. The Noir Marron data already published are coded "NM". The Mel5 and VAN136 strains were used as out-group. The HTLV-1 strains were aligned with the DAMBE program (version 4.2.13). The final alignment was submitted to the Modeltest program (version 3.6) to select, according to the Akaike Information Criterion (AIC), the best model to apply to phylogenetic analyses. The selected model was the GTR. Bootstrap support (1,000 replicates) is noted on the branch of the tree.

three different genetic systems, strengthens this conclusion. Although each parental lineage presents European and/or Amerindian contribution, the bulk ( $>95 \%)$ of their genetic diversity is inherited from African ancestors. Indeed, $99.3 \%$ of the mtDNA genetic profile of the Noir Marron comes from Africa, whereas the paternal African ancestry increases to $97.6 \%$ and the HTLV-1 strains, probably of African origin, represent 6/ 
8 for the LTR and 20/23 for the env region. Thus, despite four centuries in America, neighboured by European settlers and Amerindian ethnic groups with whom the Noir Marron made cultural exchanges [3], none or restricted gene flow has influenced their African genetic identity. This emphasises the role of the maroon identity in shaping their genetic profile. Although exchanges were necessary for the survival of the community, the ethnic integrity of the maroon society is characterised by a struggle against foreign threats, and above all the struggles of former slavers. Thus, interethnic couples, which effectively exist as between the Aluku and the Wayana [3], would contradict this cultural rule. This does not mean that the Noir Marron have been genetically isolated in the equatorial forest as revealed by their genetic diversity $\left(\mathrm{H}_{\mathrm{mtDNA}}=0.988 ; \mathrm{H}_{\mathrm{NRY}}=\right.$ 0.990). Comparable to the values of African populations, these values reflect the mass arrival of slaves into the Guianas over four centuries, an important proportion of which increased the number of the Noir Marron. Genetic diversities do not seem to have been impacted by demographic crises or geographical isolations which could have occurred during the history of Noir Marron which was punctuated by many conflicts $(\mathrm{D}=-0.55$ (0.357); Table 1). Although some communities were briefly reduced to a hundred individuals, as the Aluku were [3], the constant flow of new maroons balanced the genetic lost (Figures 3 and 6). Forming sustainable groups, still increasing in number, their adaptation to the Guianese context has been facilitated. Their maroon identity, their adaptation to the Amazonian environment and the relatively important number of immigrants explain why the Noir Marron, who today constitute 30,000 individuals in French Guiana, have conserved their African genetic inheritance.

These characteristics are all the more interesting when compared with other African American groups. The composition of the uniparental haplogroups of this African gene pool is close to observations in other African American populations, notably because of the high frequencies of L2a (22,5\%) and L1c (19\%) for the maternal lineage and E1b1a (88\%) for the paternal lineage (Figures 3 and 6), such in African American in the United States $(\mathrm{L} 1 \mathrm{c}=11 \% ; \mathrm{L} 2 \mathrm{a}=19 \%$; E1b1a $=62 \%)$ or in Afro-Brazilian in Porto Alegre (L1c $=14 \%$; L2a $=17 \%$; $\mathrm{E} 1 \mathrm{~b} 1 \mathrm{a}=44 \%)[40,46,84]$. As most of the slavers traded along the Atlantic coast of Africa, the average composition of each lineage is similar among the African American group. If this ancestral genetic pool was effectively common, the evolution of each one has produced highly divergent patterns. The population pairwise Fst comparisons of both uniparental systems showed that the majority of African American groups presented significant genetic differences from the Noir Marron
(Fst $>0.25$; Figures 4 and 7). The discrepancies are mainly due to European and/or Amerindian contributions, which are most often sex-biased [85]. This preferential gene flow is partly due to the importance of European male migration and an easier acceptance of Amerindian women in tri-hybridised communities [86]. The African inheritance of the Noir Marron, consequently not sexbiased, is peculiar in the African American landscape. Even their neighbouring African American communities are much more hybridised, as observed in North East Brazil $[5,47,48,50,79-81]$. If this characteristic is mainly shaped by their maroon identity, it is surprising to notice that other maroon groups present an admixed and sex-biased genetic profile, such as the Maroons in Jamaica (African maternal lineage: 87\%; African paternal lineage: 58\%) [45]. Even the Curiau quilombo, which could have originated from the same plantations as the Noir Marron, present a highly hybridised genetic profile (African maternal lineage: 54\%; African paternal lineage: 37\%) [81]. Furthermore, most maroon groups have lost a part of their genetic diversity after genetic drift due to their relative isolation, as has occurred in the Garifuña in Honduras $\left(\mathrm{H}_{\text {mtDNA }}=0.897\right)$ [87] and in the Angolares in the African island of São Tomé $\left(\mathrm{H}_{\mathrm{mtDNA}}=\right.$ 0.919) $[88,89]$. Thus, the Noir Marron are also genetically original within the maroon populations cluster. The reason for this difference can be enlightened by examining the groups presenting similar patterns in both lineages $($ Fst $<0.15)$. They are all located on the East coast of the United States, such as the Gullah/Geechee in South Carolina [43,78]. Although these groups never present an estimated African ancestry as high as in the Noir Marron, they present a low sex-bias. A historical cultural phenomenon can be evoked to link this common pattern. Although assimilation of Amerindian and African women was encouraged as a strategy for the occupation in Portuguese colonies [90], tolerated in Spanish territories [1], it was not the case in French, English and Dutch colonies [91,92]. Such cultural traits have favoured inter-ethnic admixture in the first case and separated communities in the second. The common behaviours in these colonies have caused a low level of sex-biased admixture, bringing the gene pools of the Noir Marron and the African Americans of the East coast of the United States closer. The combination of the maroon identity in the former Dutch colony has preserved the African genetic diversity of the Noir Marron ancestors.

\section{Retracing the African origin}

The exceptional conservation of the African genetic diversity allows a relevant picture of the genetic inheritance of slaves that were deported to the Guianas to be determined. If the African inheritance is genetically 
marked by the predominance of $\mathrm{L}^{*}$ haplogroup in maternal lineages, E1b1* in paternal lineages and HTLV-1 A strains of African origin, the detailed examination of each of these components gives a more precise location of their ancestries [31,76]. Indeed, a close link with West African populations, also suggested by the Gm system analysis [7], is identifiable through the relatively high frequencies of some mtDNA subhaplogroups as L2a1 (22.5\%), L1b (14.1\%), L3d (3.5\%), L3f1 (3.5\%), NRY sub-haplogroups as E1b1a7* (33.3\%) and E1b1a8* (21.4\%) [31,76]. Most of the HTLV-1 Noir Marron strains analysed were clustered with West African strains originating from the Ivory Coast, Ghana, Senegal and Burkina-Faso (Figure 9). Secondly, genetic relationships between the Noir Marron and South West African populations can be distinguished. Although no HTLV-1 B and D subtypes (Central African genotypes) were detected among the studied samples, the observed frequencies of mtDNA sub-haplogroups L1c1 (12.7\%) and L3e2 (7.4\%), and the NRY sub-haplogroup B (4.7\%) $[9,31,62]$ sign the link between the Noir Marron and South West Africa. These two genetic affinities were confirmed by cross-comparisons between the gene pools of the Noir Marron and each African population (Figures 4 and 7). The ethnic groups inhabiting West and South West Africa presented the lowest genetic divergence (Fst < 0.15) compared with other African groups, at the noticeable exception of the Pygmy communities, the Fang and some groups from Senegal, Chad and Niger. North Africans, East Africans and Khoisans (Fst $>0.25$ ) have not contributed to the Noir Marron gene pool, confirming that the presence of NRY haplogroups A and B are probably of South West African inheritance. The West and South West African mixedancestry of the Noir Marron is attested by FCA performed for each lineage, plotting the Noir Marron diversity inside a cluster of these populations (Figures 5 and 8). As hypothesised, the populations located in the historical regions of slavery are the most probable Noir Marron ancestors.

Despite the fact that the relative genetic homogeneity within these populations make any grouping non-significant, as reported in many studies [41,93], historical data give a strong significance to the clustering because of their importance during the Atlantic Slave Trade. All estimators of ancestry, for both uniparental systems, state the Gold Coast and the Bight of Benin as the major origin of the Noir Marron's ancestors (mtDNA: $\mathrm{LS}=0.29 ; m Y=0.64 ; \mathrm{NRY}: \mathrm{LS}=0.28 ; m Y=0.74$; Tables 2 and 3). A region also suggested by the phylogenetic analyses of the HTLV-1 strains (Figure 9 and Additional file 5). These converging results are concordant with historical records showing that this region was the port of departure of slaves who were deported to the Guianas [2]. Almost 224,000 individuals, natives of the Gold Coast and the Bight of Benin, were sold as slaves to work in the Guianese plantations. Their relative importance has largely imprinted the genetic background of the Noir Marron but also their culture. For example, Akan words are still present in their vocabulary; their pantheon is largely inherited from those present in populations in Ghana; funeral rites are common with Fanti-Ashanti customs [3]. Thus, the Noir Marron culture and genes have kept the traces of individuals coming from the Gold Coast and the Bight of Benin, a region largely impacted by the Atlantic Slave Trade.

As highlighted by historical data, slaves never came from a unique region and the Noir Marron gene pool has also kept this characteristic. Indeed, other ancestries are detected in uniparental systems, in a sex-biased manner, contradictory to the Gold Coast and the Bight of Benin origin. The majority of the remaining maternal ancestry is located in the Bight of Biafra (LS $=0.19 ; m Y$ $=0.13$; Tables 2) and in South West Africa (LS = 0.28; $m Y=0.23$; Tables 2), while the largest part of the remaining paternal ancestry is located in the region of the Windward Coast, Senegambia and Sierra Leone (LS $=0.25 ; m Y=0.26$; Tables 3$)$. Thus, a sex-biased ancestry is detected in the Noir Marron gene pool. From a major origin in the Gold Coast and the Bight of Benin, a paternal gradient goes north, while a maternal gradient goes south. This divergent geographical gradient of the uniparental ancestries may be explained by regionalspecific characteristics of trading during the Atlantic Slave Trade. In the Windward Coast, Senegambia and Sierra Leone, slave trade was also implied in the TransSaharan Slave Trade [94] in which women were more sold than men, reducing the number of women sent to the Americas. Men from these regions were judged by European settlers to be more robust than Angolans to work in the plantations, raising the demand of male slaves in these trading posts, such as in the Gorée Island. The maternal gradient, more surprisingly, may be the consequence of these practices. The rising price of male slaves from the Windward Coast, Senegambia and Sierra Leone would have forced the slavers to balance the cost of buying slaves in the south, where slave markets were created for the Atlantic Slave Trade, without competition from the Arab traders. Thus, in the Bight of Biafra and South West Africa, slavers could have bought more women to maintain a sex-ratio close to $2 / 3$ men and $1 / 3$ women [1].

\section{Conclusions}

Belonging to the wide African American cultural area, the Noir Marron in French Guiana is unique due to their African gene pool. Despite four centuries neighboured by Europeans and Amerindians with whom 
intense cultural exchanges were made, their maroon identity has limited gene flow. The conservation of the African diversity in each genetic system studied revealed a probable non-altered inheritance from their slave ancestors. A major origin was located on the Gold Coast and in the Bight of Benin; regions highly impacted by slavery. From this region, uniparental genetic markers showed a sex-biased origin, with the remaining male ancestry located from Senegal to Benin, and the remaining female ancestry from the Ivory Coast to Angola. Different historical and cultural traits of the Slave Trade have created a differential migration of the female and male enslaved ancestors of the Noir Marron. Thus, this sex-biased African ancestry is still genetically imprinted in the Noir Marron gene pool, a characteristic that deserves to be examined in other African American groups, such as the Creoles, in order to gain a relevant picture of the dynamics of the African gene flow that occurred during the Slave Trade.

\section{Additional material}

Additional file 1: References of the populations compiled in the databases used for the comparisons to Noir Marron data. Additional file 2: MtDNA haplotypes and their respective haplogroup classification found in Noir Marron, Beninese, Yacouba and Ahizi sampling

Additional file 3: AMOVA analyses performed with mtDNA and NRY data to compare the Noir Marron gene pool with the ones of the databases.

Additional file 4: NRY haplotypes and their respective haplogroup classification found in Noir Marron, Beninese, Yacouba and Ahizi sampling.

Additional file 5: LTR phylogenetic tree constructed by the neighbour-joining method of HTLV-1 strains in 8 Noir Marron (in red) and HTLV-1 sequences of the database. The Noir Marron data already published are coded "NM". The H24 strain was used as outgroup. The HTLV-1 strains were aligned with the DAMBE program (version 4.2.13). The final alignment was submitted to the Modeltest program (version 3.6) to select, according to the Akaike Information Criterion (AIC), the best model to apply to phylogenetic analyses. The selected model was the GTR. Bootstrap support (1,000 replicates) is noted on the branch of the tree.

\footnotetext{
Acknowledgements

We are grateful to all the people who contributed to the collection of blood samples, notably André Chaventré and Gil Bellis (samples from Ivory Coast). We wish to acknowledge support from the CRGS platform of Genopole Toulouse Midi Pyrénées, where mtDNA and NRY sequencing/genotyping work was performed. We are grateful for the scientific support of the Service de Protection Maternelle et Infantile de Guyane and the Centre de Prévention et de Vaccination de St Laurent du Maroni (D. Gaquière et Dr. B. Fougère). This work was partially financed by the following research grants: Programme Interdisciplinaire CNRS "Amazonie - Analyse, modélisation et ingénierie des systèmes amazoniens"; The French Agence Nationale de Recherche (2006 Microbiologie-06MIME-017-01). We thank Dan Zadik and Patricia Balaresque for their help in the $\mathrm{Y}$-haplogroup predictions inferred from STR data and Luis L Quintana-Murci for discussions and critical reading of the manuscript.
}

\section{Author details}

'Laboratoire d'Anthropobiologie Moléculaire et Imagerie de Synthèse, CNRS and Université Paul Sabatier, FRE2960, Toulouse, France. ${ }^{2}$ Unité d'Epidémiologie et Physiopathologie des Virus Oncogènes, Institut Pasteur, Paris, France. ${ }^{3}$ Institut de Recherche pour le Développement (IRD) UMR 216 Mère et enfant face aux infections tropicales \& Faculté de Pharmacie, Université Paris Descartes, Paris, France. ${ }^{4}$ Institut National de la Santé et de la Recherche Médicale, U980, Paris, France.

\section{Authors' contributions}

NB carried out genetic laboratory analysis of uniparental markers, analysed the data and drafted the manuscript. OC carried out HTLV-1 genetic analysis and the phylogenetic analysis. LT contributed with the experimental design for uniparental markers. EG extracted DNA from African samples. PT and SP participated in obtaining of the Noir Marron sampling. FMN provided the Beninese sampling. JMD, AG and GL conceived and directed the study. All authors reviewed the manuscript during its drafting and approved the final version.

Received: 25 February 2010 Accepted: 19 October 2010 Published: 19 October 2010

\section{References}

1. Klein HS: The Atlantic Slave Trade. Cambridge: Cambridge University Press 1999.

2. Eltis D, Behrendt SD, Richardson D, Klein HS: The Trans-Atlantic Slave Trade: A Database on CD-ROM. Cambridge 1999.

3. Price R, Price S: Les Marrons en Guyane. Châteauneuf-le-Rouge: Vents d'Ailleurs 2002.

4. Muniz YC, Ferreira LB, Mendes-Junior CT, Wiezel CE, Simoes AL: Genomic ancestry in urban Afro-Brazilians. Ann Hum Biol 2008, 35(1):104-111.

5. Bortolini MC, Da Silva WAJW, De Guerra DC, Remonatto G, Mirandola R, Hutz MH, Weimer TA, Silva MC, Zago MA, Salzano FM: African-derived South American populations: A history of symmetrical and asymmetrical matings according to sex revealed by bi- and uni-parental genetic markers. Am J Hum Biol 1999, 11(4):551-563.

6. Parra EJ, Kittles RA, Argyropoulos G, Pfaff CL, Hiester K, Bonilla C, Sylvester N, Parrish-Gause D, Garvey WT, Jin L, et al: Ancestral proportions and admixture dynamics in geographically defined African Americans living in South Carolina. Am J Phys Anthropol 2001, 114(1):18-29.

7. Brucato N, Tortevoye P, Plancoulaine S, Guitard E, Sanchez-Mazas A, Larrouy G, Gessain A, Dugoujon JM: The genetic diversity of three peculiar populations descending from the slave trade: $\mathrm{Gm}$ study of Noir Marron from French Guiana. C R Biol 2009, 332(10):917-926.

8. Dugoujon JM, Hazout S, Loirat F, Mourrieras B, Crouau-Roy B, SanchezMazas A: GM haplotype diversity of 82 populations over the world suggests a centrifugal model of human migrations. Am J Phys Anthropol 2004, 125(2):175-192.

9. Karafet TM, Mendez FL, Meilerman MB, Underhill PA, Zegura SL, Hammer MF: New binary polymorphisms reshape and increase resolution of the human $\mathrm{Y}$ chromosomal haplogroup tree. Genome Res 2008, 18(5):830-838.

10. van Oven $M$, Kayser M: Updated comprehensive phylogenetic tree of global human mitochondrial DNA variation. Hum Mutat 2009, 30(2): E386-394.

11. Gessain A, Gallo RC, Franchini G: Low degree of human T-cell leukemia/ lymphoma virus type I genetic drift in vivo as a means of monitoring viral transmission and movement of ancient human populations. J Virol 1992, 66(4):2288-2295.

12. Miura $T$, Fukunaga $T$, Igarashi $T$, Yamashita M, Ido E, Funahashi $S$, Ishida $T$, Washio K, Ueda S, Hashimoto K, et al: Phylogenetic subtypes of human Tlymphotropic virus type I and their relations to the anthropological background. Proc Natl Acad Sci USA 1994, 91(3):1124-1127.

13. Plancoulaine $S$, Buigues RP, Murphy EL, van Beveren M, Pouliquen JF, Joubert M, Remy F, Tuppin P, Tortevoye P, de The G, et al: Demographic and familial characteristics of HTLV-1 infection among an isolated, highly endemic population of African origin in French Guiana. Int $J$ Cancer 1998, 76(3):331-336.

14. Plancoulaine $S$, Gessain A, Joubert M, Tortevoye P, Jeanne I, Talarmin A, de The $\mathrm{G}$, Abel L: Detection of a major gene predisposing to human $\mathrm{T}$ 
lymphotropic virus type I infection in children among an endemic population of African origin. J Infect Dis 2000, 182(2):405-412.

15. Plancoulaine S, Gessain A, Tortevoye P, Boland-Auge A, Vasilescu A, Matsuda F, Abel L: A major susceptibility locus for HTLV-1 infection in childhood maps to chromosome 6q27. Hum Mol Genet 2006, 15(22):3306-3312.

16. Ureta-Vidal A, Angelin-Duclos C, Tortevoye P, Murphy E, Lepere JF, Buigues RP, Jolly N, Joubert M, Carles G, Pouliquen JF, et al: Mother-tochild transmission of human T-cell-leukemia/lymphoma virus type I: implication of high antiviral antibody titer and high proviral load in carrier mothers. Int J Cancer 1999, 82(6):832-836.

17. Excoffier L, Laval G, Schneider S: Arlequin (version 3.0): An integrated software package for population genetics data analysis. Evol Bioinform Online 2005, 1:47-50.

18. Coudray C, Olivieri A, Achilli A, Pala M, Melhaoui M, Cherkaoui M, ElChennawi F, Kossmann M, Torroni A, Dugoujon JM: The complex and diversified mitochondrial gene pool of Berber populations. Ann Hum Genet 2009, 73(2):196-214.

19. Andrews RM, Kubacka I, Chinnery PF, Lightowlers RN, Turnbull DM, Howell N: Reanalysis and revision of the Cambridge reference sequence for human mitochondrial DNA. Nat Genet 1999, 23(2):147.

20. Brion M, Sobrino B, Blanco-Verea A, Lareu MV, Carracedo A: Hierarchical analysis of $30 \mathrm{Y}$-chromosome SNPs in European populations. Int I Legal Med 2005, 119(1):10-15.

21. Hammer MF, Spurdle AB, Karafet T, Bonner MR, Wood ET, Novelletto A, Malaspina P, Mitchell RJ, Horai S, Jenkins T, et al: The geographic distribution of human Y chromosome variation. Genetics 1997, 145(3):787-805.

22. Kazanji M, Gessain A: Human T-cell Lymphotropic Virus types I and II (HTLV-I/II) in French Guiana: clinical and molecular epidemiology. Cad Saude Publica 2003, 19(5):1227-1240

23. Tortevoye P, Tuppin P, Peneau C, Carles G, Gessain A: Decrease of human T-cell lymphotropic virus type I prevalence and low incidence among pregnant women from a high endemic ethnic group in French Guiana. Int J Cancer 2000, 87(4):534-538.

24. Tuppin P, Lepere JF, Carles G, Ureta-Vidal A, Gerard Y, Peneau C, Tortevoye P, de The G, Moreau JP, Gessain A: Risk factors for maternal HTLV-I infection in French Guiana: high HTLV-I prevalence in the Noir Marron population. J Acquir Immune Defic Syndr Hum Retrovirol 1995, 8(4):420-425

25. Moynet D, Pouliquen JF, Londos-Gagliardi D, Buigues RP, Moreau JF, Bedjabaga I, Georges MC, Talarmin A, Joubert M, Fleury H, et al: High variability of HTLV-I in a remote population of Gabon as compared to that of a similar population of French Guiana. Virus Genes 2001, 23(3):257-261.

26. Mahieux R, Horal P, Mauclere P, Mercereau-Puijalon O, Guillotte M, Meertens L, Murphy E, Gessain A: Human T-cell lymphotropic virus type 1 gag indeterminate western blot patterns in Central Africa: relationship to Plasmodium falciparum infection. I Clin Microbiol 2000, 38(11):4049-4057.

27. Meertens L, Rigoulet J, Mauclere P, Van Beveren M, Chen GM, Diop O, Dubreuil G, Georges-Goubot MC, Berthier JL, Lewis J, et al: Molecular and phylogenetic analyses of 16 novel simian T cell leukemia virus type 1 from Africa: close relationship of STLV-1 from Allenopithecus nigroviridis to HTLV-1 subtype B strains. Virology 2001, 287(2):275-285

28. Cassar O, Capuano C, Bassot S, Charavay F, Duprez R, Afonso PV, Abel M, Walter H, Mera W, Martin PM, et al: Human T lymphotropic virus type 1 subtype C melanesian genetic variants of the Vanuatu Archipelago and Solomon Islands share a common ancestor. J Infect Dis 2007, 196(4):510-521.

29. Cassar O, Capuano C, Meertens L, Chungue E, Gessain A: Human T-cell leukemia virus type 1 molecular variants, Vanuatu, Melanesia. Emerg Infect Dis 2005, 11(5):706-710

30. Schlecht J, Kaplan ME, Barnard K, Karafet T, Hammer MF, Merchant NC: Machine-learning approaches for classifying haplogroup from $Y$ chromosome STR data. PLoS Comput Biol 2008, 4(6):e1000093.

31. Salas A, Richards M, De la Fe T, Lareu MV, Sobrino B, Sanchez-Diz P, Macaulay V, Carracedo A: The making of the African mtDNA landscape. Am J Hum Genet 2002, 71(5):1082-1111.
32. Salas A, Richards M, Lareu MV, Scozzari R, Coppa A, Torroni A, Macaulay V, Carracedo A: The African diaspora: mitochondrial DNA and the Atlantic slave trade. Am J Hum Genet 2004, 74(3):454-465.

33. Forster $P$, Torroni $A$, Renfrew $C$, Rohl A: Phylogenetic star contraction applied to Asian and Papuan mtDNA evolution. Mol Biol Evol 2001, 18(10):1864-1881.

34. Polzin TDSV: On Steiner trees and minimum spanning trees in hypergraphs. Operations Research Letters 2003, 32:12-20.

35. Tishkoff SA, Gonder MK, Henn BM, Mortensen H, Knight A, Gignoux C Fernandopulle N, Lema G, Nyambo TB, Ramakrishnan U, et al: History of click-speaking populations of Africa inferred from mtDNA and $Y$ chromosome genetic variation. Mol Biol Evol 2007, 24(10):2180-2195.

36. Maca-Meyer N, Arnay M, Rando JC, Flores C, Gonzalez AM, Cabrera VM, Larruga JM: Ancient mtDNA analysis and the origin of the Guanches. Eur J Hum Genet 2004, 12(2):155-162.

37. Dupanloup I, Bertorelle G: Inferring admixture proportions from molecular data: extension to any number of parental populations. Mol Biol Evol 2001, 18(4):672-675.

38. Salas A, Carracedo A, Richards M, Macaulay V: Charting the ancestry of African Americans. Am J Hum Genet 2005, 77(4):676-680.

39. Achilli A, Rengo C, Battaglia V, Pala M, Olivieri A, Fornarino S, Magri C, Scozzari R, Babudri N, Santachiara-Benerecetti AS, et al: Saami and Berbersan unexpected mitochondrial DNA link. Am J Hum Genet 2005, 76(5):883-886

40. Allard MW, Polanskey D, Miller K, Wilson MR, Monson KL, Budowle B: Characterization of human control region sequences of the African American SWGDAM forensic mtDNA data set. Forensic Sci Int 2005, 148(23):169-179.

41. Ely B, Wilson $\mathrm{JL}$, Jackson F, Jackson BA: African-American mitochondrial DNAs often match mtDNAs found in multiple African ethnic groups. BMC Biol 2006, 4:34.

42. Melton T, Clifford S, Kayser M, Nasidze I, Batzer M, Stoneking M: Diversity and heterogeneity in mitochondrial DNA of North American populations. J Forensic Sci 2001, 46(1):46-52.

43. Lind JM, Hutcheson-Dilks HB, Williams SM, Moore JH, Essex M, Ruiz-Pesini E, Wallace DC, Tishkoff SA, O'Brien SJ, Smith MW: Elevated male European and female African contributions to the genomes of African American individuals. Hum Genet 2007, 120(5):713-722.

44. Monsalve MV, Hagelberg E: Mitochondrial DNA polymorphisms in Carib people of Belize. Proc Biol Sci 1997, 264(1385):1217-1224.

45. Benn-Torres J, Bonilla C, Robbins CM, Waterman L, Moses TY, Hernandez W, Santos ER, Bennett F, Aiken W, Tullock T, et al: Admixture and population stratification in African Caribbean populations. Ann Hum Genet 2008, 72(Pt 1):90-98

46. Hunemeier T, Carvalho C, Marrero AR, Salzano FM, Pena SDJ, Bortolini MC Niger-Congo speaking populations and the formation of the Brazilian gene pool: mtDNA and Y-chromosome data. Am J Phys Anthropol 2007, 133(2):854-867.

47. Silva WA, Bortolini MC, Schneider MP, Marrero A, Elion J, Krishnamoorthy R, Zago MA: MtDNA haplogroup analysis of black Brazilian and subSaharan populations: implications for the Atlantic slave trade. Hum Biol 2006, 78(1):29-41.

48. Batista dos Santos SE, Rodrigues JD, Ribeiro-dos-Santos AK, Zago MA: Differential contribution of indigenous men and women to the formation of an urban population in the Amazon region as revealed by mtDNA and Y-DNA. Am J Phys Anthropol 1999, 109(2):175-180.

49. Ribeiro-dos-Santos AK, Carvalho BM, Feio-dos-Santos AC, dos Santos SE: Nucleotide variability of $\mathrm{HV}-\mathrm{I}$ in Afro-descendents populations of the Brazilian Amazon Region. Forensic Sci Int 2007, 167(1):77-80.

50. Carvalho BM, Bortolini MC, Batista dos Santos SE, Ribeiro-dos-Santos AK: Mitochondrial DNA mapping of social-biological interactions in Brazilian Amazonian African-descendant populations. Genetics and Molecular Biology 2008, 31(1):12-22

51. Feio-Dos-Santos AC, Carvalho BM, Batista dosSantos SE, Ribeiro-dosSantos AK: Nucleotide variability of HV-I in admixed population of the Brazilian Amazon Region. Forensic Sci Int 2006, 164(2-3):276-277.

52. Rando JC, Pinto F, Gonzalez AM, Hernandez M, Larruga JM, Cabrera VM, Bandelt HJ: Mitochondrial DNA analysis of northwest African populations reveals genetic exchanges with European, near-eastern, and subSaharan populations. Ann Hum Genet 1998, 62(Pt 6):531-550. 
53. Brehm A, Pereira L, Bandelt HJ, Prata MJ, Amorim A: Mitochondrial portrait of the Cabo Verde archipelago: the Senegambian outpost of Atlantic slave trade. Ann Hum Genet 2002, 66(Pt 1):49-60.

54. Jackson BA, Wilson JL, Kirbah S, Sidney SS, Rosenberger J, Bassie L, Alie JA, McLean DC, Garvey WT, Ely B: Mitochondrial DNA genetic diversity among four ethnic groups in Sierra Leone. Am J Phys Anthropol 2005, 128(1):156-163.

55. Rosa A, Brehm A, Kivisild T, Metspalu E, Villems R: MtDNA profile of West Africa Guineans: towards a better understanding of the Senegambia region. Ann Hum Genet 2004, 68(Pt 4):340-352.

56. Watson E, Bauer $K$, Aman R, Weiss G, von Haeseler A, Paabo S: mtDNA sequence diversity in Africa. Am J Hum Genet 1996, 59(2):437-444.

57. Rowold DJ, Luis JR, Terreros MC, Herrera RJ: Mitochondrial DNA geneflow indicates preferred usage of the Levant Corridor over the Horn of Africa passageway. J Hum Genet 2007, 52(5):436-447.

58. Coia V, Destro-Bisol G, Verginelli F, Battaggia C, Boschi I, Cruciani F, Spedini G, Comas D, Calafell F: Brief communication: mtDNA variation in North Cameroon: lack of Asian lineages and implications for back migration from Asia to sub-Saharan Africa. Am J Phys Anthropol 2005, 128(3):678-681.

59. Cerny V, Salas A, Hajek M, Zaloudkova M, Brdicka R: A bidirectional corridor in the Sahel-Sudan belt and the distinctive features of the Chad Basin populations: a history revealed by the mitochondrial DNA genome. Ann Hum Genet 2007, 71(Pt 4):433-452.

60. Destro-Bisol G, Coia V, Boschi I, Verginelli F, Caglia A, Pascali V, Spedini G, Calafell $F$ : The analysis of variation of mtDNA hypervariable region 1 suggests that Eastern and Western Pygmies diverged before the Bantu expansion. Am Nat 2004, 163(2):212-226.

61. Batini C, Coia V, Battaggia C, Rocha J, Pilkington MM, Spedini G, Comas D, Destro-Bisol G, Calafell F: Phylogeography of the human mitochondrial L1c haplogroup: genetic signatures of the prehistory of Central Africa. Mol Phylogenet Evol 2007, 43(2):635-644

62. Quintana-Murci L, Quach H, Harmant C, Luca F, Massonnet B, Patin E, Sica L, Mouguiama-Daouda P, Comas D, Tzur S, et al: Maternal traces of deep common ancestry and asymmetric gene flow between Pygmy huntergatherers and Bantu-speaking farmers. Proc Natl Acad Sci USA 2008, 105(5):1596-1601.

63. Ingman M, Kaessmann H, Paabo S, Gyllensten U: Mitochondrial genome variation and the origin of modern humans. Nature 2000, 408(6813):708-713.

64. Mateu E, Comas D, Calafell F, Perez-Lezaun A, Abade A, Bertranpetit J: A tale of two islands: population history and mitochondrial DNA sequence variation of Bioko and Sao Tome, Gulf of Guinea. Ann Hum Genet 1997, 61(Pt 6):507-518.

65. Coelho M, Sequeira F, Luiselli D, Beleza S, Rocha J: On the edge of Bantu expansions: $m t D N A, Y$ chromosome and lactase persistence genetic variation in southwestern Angola. BMC Evol Biol 2009, 9(80).

66. Beleza S, Gusmao L, Amorim A, Carracedo A, Salas A: The genetic legacy of western Bantu migrations. Hum Genet 2005, 117(4):366-375.

67. Soodyall $H$, Vigilant $L$, Hill AV, Stoneking $M$, Jenkins T: mtDNA controlregion sequence variation suggests multiple independent origins of an "Asian-specific" 9-bp deletion in sub-Saharan Africans. Am J Hum Genet 1996, 58(3):595-608.

68. Pinto F, Gonzalez AM, Hernandez M, Larruga JM, Cabrera VM: Genetic relationship between the Canary Islanders and their African and Spanish ancestors inferred from mitochondrial DNA sequences. Ann Hum Genet 1996, 60(Pt 4):321-330.

69. Vigilant L, Stoneking M, Harpending H, Hawkes K, Wilson AC: African populations and the evolution of human mitochondrial DNA. Science 1991, 253(5027):1503-1507.

70. Krings M, Salem AE, Bauer K, Geisert H, Malek AK, Chaix L, Simon C, Welsby D, Di Rienzo A, Utermann G, et al: mtDNA analysis of Nile River Valley populations: A genetic corridor or a barrier to migration? Am J Hum Genet 1999, 64(4):1166-1176.

71. Castri L, Tofanelli S, Garagnani P, Bini C, Fosella X, Pelotti S, Paoli G, Pettener D, Luiselli D: mtDNA variability in two Bantu-speaking populations (Shona and Hutu) from Eastern Africa: implications for peopling and migration patterns in sub-Saharan Africa. Am J Phys Anthropol 2009, 140(2):302-311.
72. Horai S, Hayasaka K: Intraspecific nucleotide sequence differences in the major noncoding region of human mitochondrial DNA. Am J Hum Genet 1990, 46(4):828-842.

73. Caglia A, Tofanelli S, Coia V, Boschi I, Pescarmona M, Spedini G, Pascali V, Paoli G, Destro-Bisol G: A study of Y-chromosome microsatellite variation in sub-Saharan Africa: a comparison between $\mathrm{F}(\mathrm{ST})$ and $\mathrm{R}(\mathrm{ST})$ genetic distances. Hum Biol 2003, 75(3):313-330.

74. Rosa A, Ornelas C, Jobling MA, Brehm A, Villems R: Y-chromosomal diversity in the population of Guinea-Bissau: a multiethnic perspective. BMC Evol Biol 2007, 7:124.

75. Knight A, Underhill PA, Mortensen HM, Zhivotovsky LA, Lin AA, Henn BM, Louis D, Ruhlen M, Mountain JL: African Y chromosome and mtDNA divergence provides insight into the history of click languages. Curr Biol 2003, 13(6):464-473.

76. Cruciani F, Santolamazza P, Shen P, Macaulay V, Moral P, Olckers A, Modiano D, Holmes S, Destro-Bisol G, Coia V, et al: A back migration from Asia to sub-Saharan Africa is supported by high-resolution analysis of human Y-chromosome haplotypes. Am J Hum Genet 2002, 70(5):1197-1214.

77. Berniell-Lee G, Calafell F, Bosch E, Heyer E, Sica L, Mouguiama-Daouda P, van der Veen L, Hombert JM, Quintana-Murci L, Comas D: Genetic and demographic implications of the Bantu expansion: insights from human paternal lineages. Mol Biol Evol 2009, 26(7):1581-1589.

78. Kayser M, Brauer S, Schadlich H, Prinz M, Batzer MA, Zimmerman PA, Boatin BA, Stoneking M: Y chromosome STR haplotypes and the genetic structure of U.S. populations of African, European, and Hispanic ancestry. Genome Res 2003, 13(4):624-634.

79. Abe-Sandes K, Silva WA Jr, Zago MA: Heterogeneity of the $Y$ chromosome in Afro-Brazilian populations. Hum Biol 2004, 76(1):77-86.

80. Ribeiro GG, De Lima RR, Wiezel CE, Ferreira LB, Sousa SM, Rocha DM, Canas Mdo C, Nardelli-Costa J, Klautau-Guimaraes Mde N, Simoes AL, et al: Afroderived Brazilian populations: male genetic constitution estimated by $\mathrm{Y}$ chromosomes STRs and AluYAP element polymorphisms. Am J Hum Biol 2009, 21(3):354-356.

81. Ribeiro-dos-Santos AK, Pereira JM, Lobato MR, Carvalho BM, Guerreiro JF, Batista dosSantos SE: Dissimilarities in the process of formation of Curiau, a semi-isolated Afro-Brazilian population of the Amazon region. Am J Hum Biol 2002, 14(4):440-447.

82. Wood ET, Stover DA, Ehret C, Destro-Bisol G, Spedini G, McLeod H, Louie L, Bamshad M, Strassmann BI, Soodyall H, et al: Contrasting patterns of $Y$ chromosome and mtDNA variation in Africa: evidence for sex-biased demographic processes. Eur J Hum Genet 2005, 13(7):867-876.

83. Luis JR, Rowold DJ, Regueiro M, Caeiro B, Cinnioglu C, Roseman C, Underhill PA, Cavalli-Sforza LL, Herrera RJ: The Levant versus the Horn of Africa: evidence for bidirectional corridors of human migrations. Am J Hum Genet 2004, 74(3):532-544.

84. Hammer MF, Chamberlain VF, Kearney VF, Stover D, Zhang G, Karafet T, Walsh B, Redd AJ: Population structure of Y chromosome SNP haplogroups in the United States and forensic implications for constructing Y chromosome STR databases. Forensic Sci Int 2006, 164(1):45-55.

85. Stefflova K, Dulik MC, Pai AA, Walker AH, Zeigler-Johnson CM, Gueye SM, Schurr TG, Rebbeck TR: Evaluation of group genetic ancestry of populations from Philadelphia and Dakar in the context of sex-biased admixture in the Americas. PLoS One 2009, 4(11):e7842.

86. Sans M: Admixture studies in Latin America: from the 20th to the 21st century. Hum Biol 2000, 72(1):155-177.

87. Salas A, Richards M, Lareu MV, Sobrino B, Silva S, Matamoros M, Macaulay V, Carracedo A: Shipwrecks and founder effects: divergent demographic histories reflected in Caribbean mtDNA. Am J Phys Anthropol 2005, 128(4):855-860.

88. Coelho M, Coia C, Alves V, Luiselli D, Useli A, Hagemeijer T, Amorim A, Destro-Bisol G, Rocha J: Human Microevolution and the Atlantic Slave Trade: A Case Study from Sao Tome. Current Anthropology 2008, 49(1):134-143.

89. Trovoada MJ, Pereira L, Gusmao L, Abade A, Amorim A, Prata MJ: Pattern of $m t D N A$ variation in three populations from Sao Tome e Principe. Ann Hum Genet 2004, 68(Pt 1):40-54.

90. Cruz E: Historia do Para. Belem, Governo do Estado do Para 1973, 148.

91. Donoghue E: Black women/white men: the sexual exploitation of female slaves in the Danish West Indies. Trenton, NJ: Africa World Press 2002. 
92. Hamshere C: The British in the Caribbean. Cambridge, Mass: Harvard University Press 1972.

93. Tishkoff SA, Reed FA, Friedlaender FR, Ehret C, Ranciaro A, Froment A, Hirbo JB, Awomoyi AA, Bodo JM, Doumbo O, et al: The genetic structure and history of Africans and African Americans. Science 2009, 324(5930):1035-1044.

94. Harich N, Costa MD, Fernandes V, Kandil M, Pereira JB, Silva NM, Pereira L: The trans-Saharan slave trade - clues from interpolation analyses and high-resolution characterization of mitochondrial DNA lineages. BMC Evol Biol 2010, 10:138.

doi:10.1186/1471-2148-10-314

Cite this article as: Brucato et al:: The imprint of the Slave Trade in an African American population: mitochondrial DNA, Y chromosome and HTLV-1 analysis in the Noir Marron of French Guiana. BMC Evolutionary Biology 2010 10:314.

\section{Submit your next manuscript to BioMed Central} and take full advantage of:

- Convenient online submission

- Thorough peer review

- No space constraints or color figure charges

- Immediate publication on acceptance

- Inclusion in PubMed, CAS, Scopus and Google Scholar

- Research which is freely available for redistribution

Submit your manuscript at www.biomedcentral.com/submit 